HRVATSKI GEOGRAFSKI GLASNIK 82/1, 85-110 (2020.)

UDK 338.484:504(100)

911.3:33](100)

DOI $\quad$ 10.21861/HGG.2020.82.01.04

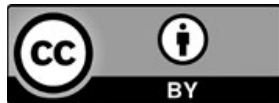

\title{
Review and evaluation of existing international systems of tourism sustainability indicators
}

\section{Pregled i evaluacija postojećih međunarodnih sustava pokazatelja održivosti turizma}

Continuous monitoring of sustainability creates the necessary information basis for effective development management of tourism in a sustainable direction. Since sustainability became a key factor in developing quality tourism products without negatively affecting the natural and cultural environment, different systems of sustainability indicators have emerged — starting around 30 years ago. The UNWTO framework for sustainability assessment along with the European Commission's ETIS system are recognised as the most important and influential systems of indicators, and there are also many new systems and sets-largely based on the UNWTO and ETIS systems. However, in spite of the existence of these systems, confusion occurs because the number of possible new systems and indicators is constantly increasing, without a clearly defined framework or scale of measurement. The abundance of systems, initiatives, and projects ultimately brings significant confusion to destination management bodies.

Key words: indicators, sustainability, tourism, systems, monitoring
Kontinuiranim praćenjem održivosti stvara se potrebna informacijska osnova za učinkovito upravljanje razvojem turizma u željenom, održivom smjeru. Kako je održivost postala ključni izazov u razvoju kvalitetnih turističkih proizvoda, prije tridesetak godina počeli su se pojavljivati različiti sustavi pokazatelja održivosti. Okvir Svjetske turističke organizacije za procjenu održivosti zajedno sa sustavom ETIS Europske komisije prepoznaje se kao najvažniji i najutjecajniji, dok postoji velik broj novih sustava pokazatelja i skupova koji se uglavnom temelje na njihovu iskustvu. Međutim, unatoč postojećim sustavima dolazi do zabune jer se broj mogućih sustava, a time i broj pokazatelja, stalno povećava, bez jasno definirana okvira i obveze mjerenja. Obilje sustava, inicijativa i u konačnici projekata stvaraju zabludu i nemaju stvaran doprinos osnovnom znanju o stanju održivosti u destinaciji.

Ključne riječi: pokazatelji, održivost, turizam, sustavi, praćenje 
HRVATSKI

GEOGRAFSKI

GLASNIK

82/1, 85-110 (2020.)

\section{Introduction}

In order to manage the development of tourism in accordance with the principles of tourism sustainability, the preliminary step of determining the current situation in relation to the three pillars, i.e. the three dimensions of sustainability, is necessary. Namely, the foundation of sustainable tourism represents a balance between three development aspects: (i) optimal use of environmental resources; (ii) fairly distributed economic benefits to all stakeholders; and (iii) respect for socio-cultural communities, which is a guarantee for long-term sustainability of all forms of tourism in all types of destinations (UNWTO, 2004). Only assessment of the situation, and the continuous monitoring of sustainability, creates the necessary information basis for effective development management in a sustainable direction.

In order to analyse the existing international systems of destination sustainability indicators, the term destination should be precisely defined. According to Flores and Scott (2016), a destination is a specific place that a tourist plans to visit, which is different from the tourist's normal environment. This can be used to describe locations at a range of scales, from an individual resort to a city, country, or even continent. The need to monitor sustainability is particularly important in destinations characterised by strong dependence on tourism, measured by the relatively large share of tourism in GDP. This category includes Croatia as a destination dominated by the tourist product of "sun and sea". One of the main characteristics of such destinations is the seasonal and spatial (geographical) concentration of tourist demand, meaning most of the tourist turnover in Croatia is recorded in the three summer months. According to data available from Croatian Bureau of Statistics (2018), 72\% of total tourist overnight stays in commercial accommodation was recorded in the June-August period in 2018. Furthermore, according to Eurostat, Croatia was characterised by an extremely high intensity of tourism in 2018. This indicator correlates the number of overnight stays with the number of permanent residents in the destination (Eurostat, 2019), and for Croatia it amounted to 14.1 in 2018, while the $\mathrm{EU}$ average is 5.0. In the EU, only small is-

\section{Uvod}

Da bi se razvojem turizma moglo upravljati $u$ skladu s načelima održivosti turizma, nužan preliminarni korak jest utvrđivanje trenutnoga stanja u odnosu na sva tri stupa, odnosno sve tri dimenzije održivosti. Naime, temelj je održivoga turizma ravnoteža između triju aspekata razvoja: (i) optimalnoga korištenja okolišnih resursa, (ii) pravedno raspodijeljene gospodarske koristi svim dionicima i (iii) poštivanja društveno-kulturnih zajednica, što je jamstvo dugoročne održivosti za sve oblike turizma u svim vrstama destinacija (UNWTO, 2004). Tek ocjenom stanja, ali i kontinuiranim praćenjem održivosti, stvara se potrebna informacijska osnova za djelotvorno upravljanje razvojem u željenom, održivom smjeru.

Da bi se analizirali postojeći međunarodni sustavi pokazatelja ${ }^{1}$ održivosti destinacija, potrebno je točno odrediti značenje pojma destinacije. Prema Floresu i Scottu (2016) destinacija je određeno mjesto koje turist planira posjetiti, a koje se razlikuje od uobičajenoga okruženja turista. Naziv se može koristiti za opisivanje lokacija različita opsega, od pojedinoga turističkog naselja do grada, države ili čak do kontinenta. Potreba za praćenjem održivosti posebno je važna u destinacijama koje karakterizira snažna ovisnost o turizmu mjerena relativno velikim udjelom turizma u bruto domaćem proizvodu. $\mathrm{U}$ tu kategoriju spada i Hrvatska kao atraktivna europska destinacija ljetnoga odmorišnog turizma. Jedna je od glavnih značajka takvih destinacija sezonska i prostorna (geografska) koncentracija turističke potražnje, tako da je većina turističkoga prometa u Hrvatskoj zabilježena u trima ljetnim mjesecima. Prema podatcima Državnoga zavoda za statistiku (2018) tijekom 2018. godine u razdoblju lipanj-kolovoz zabilježeno je $72 \%$ ukupnih noćenja turista u komercijalnom smještaju. $S$ druge strane, podatci Eurostata za 2018. pokazuju da i Republiku Hrvatsku karakterizira izrazito visok intenzitet turizma, što je pokazatelj kojim se mjeri broj noćenja u odnosu na broj stalnih rezidenata u destinaciji (Euro-

\footnotetext{
$1 \mathrm{U}$ radu se koristi naziv (termin) pokazatelj koji je istovjetan nazivu indikator (srednjovj. lat. indicator: pokazatelj), no s obzirom na to da se u domaćoj literaturi u društvenim znanostima češće upotrebljava naziv pokazatelj, a u tehničkim i kemijskim znanostima indikator, odabran je pokazatelj.
} 
land economies such as Malta (18.8) and Cyprus (16.9) have higher intensity of tourism. Additional analysis of data available from the Croatian Bureau of Statistics (2019) revealed that $95 \%$ of overnight stays was recorded in the NUTS2 region of Adriatic Croatia during 2018. Taking into account the fact that most of the tourist turnover is realised in the narrow coastal zone, it is clear that the establishment of sustainability parameters and indicators is the basis for informed and efficient management. In this light, the way sustainability is regarded is extremely important-using either scientifically and professionally based/tested systems of indicators or image-based assessments-which can ultimately create confusion and does not always contribute to the basic knowledge of the sustainability status of a given destination. Therefore, this paper aims to provide a wide overview of existing tourism sustainability practices and indicator systems. In the preliminary phase of this research, a synthesis of professional reports, papers, and websites was presented and analysed, and possible solutions were recognised. Thereby, the knowledge base of the scientific and professional literature presented in this paper served to evaluate existing tourism sustainability indicator systems.

Establishment of sustainability parameters and indicators is the basis for informed and intelligent management, i.e. decision-making. Accordingly, and due to the need to recognise the value of using certain methodologies, the purpose of this paper is to determine which systems, initiatives, and projects are most often used in determining sustainability and to what extent do the existing systems of indicators meet the needs of monitoring sustainability at the level of destinations. Another aim of this paper is to provide insight into existing problems, which have been recognised by the research, and to propose possible solutions that would enable better implementation of sustainability monitoring.

\section{An overview of previous research}

Sustainability has become a key challenge in developing quality tourism products without negatively affecting the natural and cultural environment (Kunasekaran et al., 2017). Numerous authors stat, 2019). Taj je pokazatelj za Republiku Hrvatsku u 2018. iznosio 14,1, a EU prosjek 5,0. Veći intenzitet turizma u EU imaju samo mala otočna gospodarstva poput Malte $(18,8)$ i Cipra $(16,9)$. Dodatna analiza podataka dostupnih u Državnom zavodu za statistiku (2019) otkriva da je tijekom 2018. godine $95 \%$ noćenja zabilježeno u NUTS2 regiji Jadranske Hrvatske. Uzimajući u obzir činjenicu da se većina turističkoga prometa ostvaruje u uskom obalnom pojasu, jasno je da je utvrđivanje parametara održivosti i pokazatelja osnova za informirano i učinkovito upravljanje. S obzirom na navedeno, vrlo je bitan način na koji se sagledava održivost - kroz znanstveno i stručno utemeljene i testirane sustave pokazatelja ili na temelju procjena baziranih na dojmu, koje u konačnici stvaraju zabludu i nemaju stvaran doprinos osnovnom znanju o stanju održivosti u destinaciji. Stoga će ovaj rad pružiti širok pregled postojećih praksi održivosti turizma i sustava pokazatelja. U preliminarnoj fazi ovoga istraživanja analizirani su stručni izvještaji, radovi i mrežne stranice postojećih praksi te su njihovom sintezom prepoznata problemska pitanja i moguća rješenja. Stoga je baza znanja iz znanstvene i stručne literature predstavljena u ovom radu poslužila za ocjenu postojećih sustava pokazatelja održivosti turizma.

Uspostava parametara i pokazatelja održivosti temelj su informiranoga i inteligentnoga upravljanja, odnosno, donošenja odluka. Prema tome, i radi potrebe prepoznavanja vrijednosti primjene određenih metodologija svrha je ovoga rada utvrditi koji su najkorišteniji sustavi, inicijative i projekti u određivanju održivosti i u kojoj mjeri postojeći sustavi pokazatelja zadovoljavaju potrebe praćenja održivosti na razini destinacija. Također, jedan je od ciljeva ovoga rada pružiti uvid u postojeća problemska pitanja koja su prepoznata u istraživanjima fokusiranima na testiranje sustava pokazatelja i predlaganje mogućih rješenja koja će omogućiti kvalitetniju provedbu praćenja održivosti.

\section{Pregled prethodnih istraživanja}

Održivost je postala ključni izazov u razvoju kvalitetnih turističkih proizvoda bez negativna utjecaja na prirodni i kulturni okoliš (Kunasekaran i dr., 2017). Brojni autori u znanstvenoj
I. Marković Vukadin M. Zovko

D. Krešić

Review and evaluation of existing

international systems of tourism sustainability indicators

Pregled i evaluacija postojećih

međunarodnih sustava pokazatelja održivosti turizma 
GEOGRAFSKI

GLASNIK

82/1, 85-110 (2020.) have recognised the importance of implementation of indicators in order to strengthen socio-ecological systems under the intense influence of tourism (Lacitignola et al., 2007; Krajinović, 2015). Indicators for sustainable tourism may exist at national, regional, and destination levels and they have socio-cultural, economic, and environmental dimensions (Ceron, 2003; Gebhard et al., 2007). Each dimension has one or more themes (issues). There are also indicators derived from these themes. Furthermore, the literature alleges numerous indicators for sustainable tourism development. In the analysed literature, we can identify two different approaches: focus on indicators dealing exclusively (or almost exclusively) with environmental issues, such as indicators of the European Environment Agency (Pulido and Sanchez, 2009) and another approach that puts the same focus on all three dimensions of tourism sustainability (Tsaur et al., 2006; Blancas et al., 2010; Castellani and Sala, 2010), which is the practice of the United Nations World Tourism Organisation. Sustainability indicators are essential: i) to monitor sectoral development so as to facilitate the assessment of tourism policies and practices; ii) to measure sectoral progress and develop suitable strategies for a preferred future; and iii) to communicate knowledge via the generation of quantitative and objective data that provide a fuller understanding of tourist phenomena in their spatial context (Blancas et al., 2010; Castellani and Sala, 2010).

In the initial stages of critical discussions on sustainability indicators, Gossling et al. (2008) supported the diversification of, as they called it, measurements of socio-economic development, because using tourist arrivals numbers as the sole indicator omits the complexity of tourism-generated income. The challenges of adjusting tourism sustainability indicators, especially the challenges of adjusting destination indicators, have been extensively analysed in a great number of papers (Blancas et al., 2010; Torres-Delgado et al., 2014; Marzo-Navarro, 2015; Agyeiwaah et al., 2017)

An overview of the scientific literature of the indicators of sustainability in tourism points to differences in approaches to selecting and weighting indicators (Mikulić et al., 2015), which confirm that the use of tourism indicators remains relatively in- literaturi prepoznaju važnost primjene pokazatelja radi jačanja socioekoloških sustava pod intenzivnim utjecajem turizma (Lacitignola i dr., 2007; Krajinović, 2015). Pokazatelji održivoga turizma mogu postojati na nacionalnoj, regionalnoj i destinacijskoj razini i imaju sociokulturnu, gospodarsku i ekološku dimenziju (Ceron, 2003; Gebhard i dr., 2007). Svaka dimenzija ima jednu ili više tema (pitanja). Razvijeni su i pokazatelji iz tih tema. Nadalje, u literaturi se navode brojni pokazatelji održivoga razvoja turizma, a možemo identificirati dva različita pristupa: prvi je s fokusom na pokazatelje koji se bave isključivo (ili gotovo isključivo) pitanjima zaštite okoliša, kao što su pokazatelji Europske agencije za okoliš (Pulido i Sanchez, 2009), a drugi pristup stavlja isti fokus na sve tri dimenzije održivosti turizma (Tsaur i dr., 2006; Blancas i dr., 2010; Castellani Sala, 2010), što je praksa Svjetske turističke organizacije Ujedinjenih naroda. Pokazatelji održivosti ključni su za: i) praćenje sektorskoga razvoja kako bi se olakšala procjena turističkih politika i praksi; ii) mjerenje sektorskoga napretka i razvoj prikladnih strategija za željenu budućnost i iii) komunikaciju znanja generiranjem kvantitativnih i objektivnih podataka koji omogućuju puno razumijevanje turističkih fenomena u njihovu prostornom kontekstu (Blancas i dr., 2010; Castellani i Sala, 2010).

U začetcima kritičnih rasprava o pokazateljima održivosti Gossling i dr. (2008) podržavaju diversifikaciju, kako to nazivaju, mjerenja socioekonomskoga razvoja jer korištenje broja dolazaka turista kao jedinoga pokazatelja izostavlja složenost prihoda ostvarena turizmom. Izazovi prilagodbe pokazatelja održivosti turizma posebnim izazovima destinacija detaljno su analizirani u velikom broju radova (Blancas i dr., 2010, Torres-Delgado i dr., 2014; Marzo-Navarro, 2015; Agyeiwaah i dr., 2017).

Pregled znanstvene literature o pokazateljima održivosti u turizmu upućuje na razlike u pristupu, odabiru i ponderiranju pokazatelja (Mikulić i dr., 2015), što potvrđuje navedenu pretpostavku da praksa pokazatelja turizma ostaje relativno nedosljedna te se u velikoj mjeri temelji na široko korištenim sustavima pokazatelja ETIS-a 
consistent and is largely based on widely-used sets of the European Tourism Indicator System (ETIS) and the World Tourism Organization (UNWTO) indicators (EC, 2016; UNWTO, 2004). Scientific literature, as stated, abounds in attempts to weigh and quantify indicators, with authors turning to different methodologies (Cabello et al., 2014) that are more or less successful in this task. However, they all have a common testing methodology regarding smaller destinations (Dimoska and Petrevska, 2012; Lew et al., 2016), focusing not only on the result, but also on improving methodology (Miller, 2001; Vojnović, 2014). Indicators need to strike a balance between their contextual specificity and global relevance, to include both local and global impacts. Most sustainable tourism researchers focus on local-scale and short-term issues within administratively-defined units (Blancas et al., 2016; Torres-Delgado and Palomeque, 2018).

Considering the scientific papers in Croatia dealing with indicators, we can point out that the first research efforts that attempted to evaluate spatial indicators in tourism appeared in the 1980s (Pepeonik, 1988). Since then, a notable number of papers have made significant contributions to the knowledge of partial aspects of sustainability indicators in Croatia (Magaš, 1998; Vizek, 2008; Marić et al., 2017), selected destinations (Opačić, 2008; Slavuj et al., 2009; Glamuzina, 2011; Grofelnik, 2012; Šulc and Valjak, 2012; Vojnović, 2013), or business entities in tourism (Mrak-Taritaš, 2010; Pletikosa, 2015). It is necessary to highlight the work of Krajinović (2015), in which she examined if sustainability within a destination can be measured and if so, which measurement model was best suited to doing so. Furthermore, Vojnović also provided an excellent overview of selected research papers and, based on them, attempted to interpret and solidify indicators in Croatia and in European tourism regions that are similar to Croatia according to their geographical and tourism features. By examining the key criteria for official statistical indicator availability in Croatia, it was found that certain key indicators could not be used in monitoring sustainable tourism at the spatial level of municipalities and cities (Vojnović, 2014). i UNWTO-a (EC, 2016; UNWTO; 2004). Znanstvena literatura, kako je rečeno, obiluje pokušajima ponderiranja i kvantificiranja pokazatelja, a autori se okreću različitim metodologijama (Cabello i dr., 2014) koje su više-manje uspješne u tom zadatku. Međutim, svima im je zajedničko testiranje metodologija na manjim destinacijama (Dimoska i Petrevska, 2012; Lew i dr., 2016), s naglaskom ne samo na rezultatu, već i na poboljšanju metodologije (Miller, 2001; Vojnović, 2014). Pokazatelji trebaju postići ravnotežu između svoje kontekstualne specifičnosti i globalne važnosti kako bi uključili lokalne i globalne učinke. Većina istraživanja održivoga turizma usmjerena je na lokalna i kratkoročna pitanja unutar administrativno definiranih jedinica (Blancas i dr., 2016; Torres-Delgado i Palomeque, 2018).

Sagledavajući znanstvene radove u Hrvatskoj koji se bave pokazateljima, možemo istaknuti da su se prvi istraživački napori koji pokušavaju procijeniti prostorne pokazatelje $\mathrm{u}$ turizmu pojavili u 1980-ima (Pepeonik, 1988). Od tada je velik broj radova dao značajan doprinos poznavanju parcijalnih aspekata pokazatelja održivosti u Hrvatskoj (Magaš, 1998; Vizek, 2008; Marić i dr., 2017), odabranih destinacija (Opačić, 2008; Slavuj i dr., 2009; Glamuzina, 2011; Grofelnik, 2012; Šulc i Valjak, 2012; Vojnović, 2013) ili poslovnih subjekata u turizmu (Mrak-Taritaš, 2010; Pletikosa, 2015). Potrebno je istaknuti rad Krajinović (2015) u kojem je autorica istražila može li se mjeriti održivost destinacija u Hrvatskoj, i ako može, koji od sustava mjerenja najbolje odgovara. Nadalje, Vojnović je dao i izvrstan pregled odabranih istraživačkih radova te na temelju njih pokušao protumačiti i konkretizirati pokazatelje u Hrvatskoj i u europskim turističkim regijama koje su prema geografskim i turističkim značajkama slične Hrvatskoj. Ispitivanjem ključnih kriterija dostupnosti službenih statističkih pokazatelja u Hrvatskoj utvrđeno je da se pojedini ključni pokazatelji ne mogu koristiti u praćenju održivoga turizma na prostornoj razini općina i gradova (Vojnović, 2014).
I. Marković Vukadin M. Zovko

D. Krešić

Review and evaluation of existing international systems of tourism sustainability indicators

Pregled i evaluacija postojećih

međunarodnih sustava pokazatelja održivosti turizma 
HRVATSKI

GEOGRAFSKI

GLASNIK

82/1, 85-110 (2020.)

\section{Existing systems, initiatives, and projects of sustainable tourism measurement}

Indicators are a useful tool for measuring progress toward e.g. economic, environmental, or other defined goals. They provide an approximation and projection of society's development on the global, macro-regional, national, or destination scale which are basis for the long term planning but also for early-warning information needed for the policy change or new actions. In the field of sustainable development in tourism, diverse and specific indicators are developed via collaboration among a variety of stakeholders and an interdisciplinary approach, thus creating a basis for analysis, research, and management (Blažević et al., 2013).

\section{United Nations World Tourism Organization indicators}

In the early 1990s, the UNWTO provided the first sustainable tourism indicators to help to identify the key factors that make some destination attractive and more sustainable (EC, 2016). Therefore, assessments and conclusions drawn from collected data and agreed-upon indicators are the basis for development of preventive and corrective measures in order to maintain sustainable tourism practices and to raise awareness of sustainability issues (UNWTO, 2005; UNWTO, 2008). During next two decades many publications and reports forming the final list were published, some of the most important being: the "Glossary of environment statistics" (UN, 1997); "Commission on sustainable development work programme on indicators of sustainable development" (UN, 2001); and "Establishment of a set of indicators to monitor the integration of environmental and health aspects into transport policies, and their impacts on health and the environment" (UN, 2003).

In 2004, the UNWTO published A Guidebook: Indicators of Sustainable Development for Tourism Destinations (UNWTO, 2004). According to this methodology, development of a tourism sustainability indicator system is focused at the destination level. It is important to stress that the term destination does not necessarily refer to a single tourist site

\section{Postojeći sustavi, inicijative i projekti mjerenja održivoga turizma}

Pokazatelji su koristan alat za mjerenje napretka prema npr. ekonomskim, okolišnim ili drugim definiranim ciljevima. Oni pružaju približavanje i projekciju razvoja društva na globalnoj, makroregionalnoj, nacionalnoj ili destinacijskoj ljestvici koja je temelj za dugoročno planiranje, ali i za baze informacija koje mogu služiti kao upozorenje potrebno za promjenu politike ili nove mjere. Na području održivoga razvoja u turizmu razvijaju se različiti i specifični pokazatelji kroz suradnju različitih dionika i interdisciplinarni pristup, čime se stvaraju temelji za analizu, istraživanje i upravljanje (Blažević i dr., 2013).

\section{Sustav pokazatelja Svjetske turističke organizacije}

Početkom 1990-ih Svjetska turistička organizacija (UNWTO) osigurala je prve pokazatelje održivoga turizma koji će pomoći u prepoznavanju ključnih čimbenika koje neke destinacije čine atraktivnijima i održivijima (EC, 2016.). Stoga su procjene i zaključci dobiveni iz prikupljenih podataka i dogovorenih pokazatelja temelj za razvoj preventivnih i korektivnih mjera kako bi se zadržale prakse održivoga turizma i podigla svijest o pitanjima održivosti (UNWTO, 2005; UNWTO, 2008). Tijekom idućih dvaju desetljeća objavljen je niz publikacija i izvještaja koji su utjecali na formiranje konačne liste, a neke od najvažnijih su: „Rječnik statistike okoliša" (engl. Glossary of environment statistics) (UN, 1997), „Radni program o pokazateljima održivoga razvoja" (engl. Commission on sustainable development work programme on indicators of sustainable development) (UN, 2001) i „Uspostava skupa pokazatelja za nadgledanje integracije okolišnih i zdravstvenih aspekata u prometne politike i njihovih utjecaja na zdravlje i okoliš" (engl. Establishment of a set of indicators to monitor the integration of environmental and health aspects into transport policies, and their impacts on health and the environment) (UN, 2003).

Temeljem prikupljenih brojnih praktičnih iskustva 2004. godine objavljen je „Priručnik za uspostavu sustava pokazatelja održivosti u turizmu" (engl. Indicators of Sustainable Development for Tourism Destinati- 
but also to the region or the country as a whole. This methodology proposes three phases of implementation, and each phase is comprised of four steps. In addition, these guidelines also analyse around fifty important topics, especially the field of sustainable tourism development. For each topic, indicators were proposed at the conceptual level and a list of basic indicators, which were generally relevant and tested in various case studies, were provided. It is interesting to point out that Kukljica, Croatia study was done as a demonstration project to test the WTO indicators approach in the Mediterranean, whereby the procedure was applied on small islands in order to better integrate destination-level indicators into the local and regional planning process. The application of indicators was undertaken in Croatia, in the municipality of Kukljica that spans the linked islands of Ugljan and Pašman. This pilot action was done to bring local and expert knowledge together to define issues and indicators and to act as a catalyst for further work towards sustainable tourism. (UNWTO, 2004).

The UNWTO methodology and indicators should be understood as an initiative with the intention of building a universally applicable indicator system that could be used for any tourist destination, in any part of the world. Although this process has not yet been fully completed, the methodology and basic indicators of the UNWTO can serve as a starting point for a national, regional, or local project to develop a tourism sustainability indicator system. Given the importance of the UNWTO in shaping the monitoring processes of tourism sustainability, the following related publications should be mentioned: Sustainable Tourism in Protected Areas: Guidelines for Planning and Management (UNWTO / UNEP / IUCN, 2002); "Good examples of ecotourism practices" (UNWTO, 2008); and contributions from Tourism Concessions in Protected Natural Areas: Guidelines for Managers (UNDP, 2014).

To encourage comparable, integrated, and relevant decision making, sets of standardised sustainable tourism indicators were developed by initiatives, projects, or via establishment of an expert reporting mechanisms. One of the most important sets of sustainable tourism indicators was proposed by the ons - A Guidebook) (UNWTO, 2004). Metodologija UNWTO-a je u većoj mjeri usmjerena na razvoj sustava pokazatelja održivosti turizma na razini destinacije, pri čemu se pod pojmom destinacije ne mora nužno podrazumijevati pojedino turističko mjesto, već to može biti i čitava regija ili država u cjelini. Ovom metodologijom predlažu se tri faze implementacije procesa mjerenja, pri čemu svaku fazu čine četiri koraka. Osim detaljnog opisa same metodologije, UNWTO (2004) analizira i pedesetak važnih tema, odnosno problema održivoga razvoja turizma. Uz svaku su temu na konceptualnoj razini predloženi i pokazatelji i popis osnovnih pokazatelja koji su općenito relevantni i testirani u različitim studijama slučajeva. Zanimljivo je istaknuti da je studija Kukljica, Hrvatska rađena kao pokazni projekt za testiranje pristupa pokazatelja UNWTO-a na Sredozemlju, u svrhu testiranja sustava na malim otocima i utvrđivanja mogućnosti bolje integracije pokazatelja na razini destinacije u proces lokalnoga i regionalnoga planiranja. Primjena pokazatelja provedena je u općini Kukljica i na povezanim otocima Ugljanu i Pašmanu. Pilot-aktivnost provedena je radi objedinjavanja lokalnih i stručnih znanja u svrhu definiranja pitanja i pokazatelja, kao katalizatora za daljnji rad prema održivom turizmu. (UNWTO, 2004).

UNWTO-ovu metodologiju i pokazatelje treba shvatiti kao inicijativu čija je namjera bila izgradnja univerzalno primjenjiva sustava pokazatelja koji bi se mogao koristiti za bilo koju turističku destinaciju, u bilo kojem dijelu svijeta. Iako taj proces još uvijek nije u potpunosti završen, metodologija i osnovni pokazatelji UNWTO-a mogu poslužiti kao polazište nacionalnom, regionalnom ili lokalnom projektu razvoja sustava pokazatelja održivosti turizma. S obzirom na važnost uloge UNWTO-a u formiranju procesa mjerenja dodatno treba istaknuti publikacije s fokusom na praćenje održivosti turizma: „Smjernice za održivi razvoj i upravljanje turizmom u nacionalnim parkovima i zaštićenim područjima” (eng. Sustainable Tourism in Protected Areas: Guidelines for Planning and Management (UNWTO/UNEP/IUCN, 2002), „Primjere dobre prakse u ekoturizmu" (engl. Good examples of ecotourism practices) (UNWTO, 2008) i doprinose iz publikacije „Koncesije za turizam u zaštićenim prirodnim područjima: Smjernice za menadžere" (engl. Tourism Concessions in Protected Natural Areas: Guidelines for Managers) (UNDP, 2014).
I. Marković Vukadin M. Zovko

D. Krešić

Review and evaluation of existing

international systems of tourism sustainability indicators

Pregled i evaluacija postojećih

međunarodnih sustava pokazatelja održivosti turizma 
GEOGRAFSKI

GLASNIK

82/1, 85-110 (2020.)
Measuring Sustainable Tourism Framework (MST Framework) initiative, and commenced in late 2015 by the UN World Tourism Organization (UNWTO) in partnership with the UN Statistics Division (UNSD). The MST Framework consisted of Tourism Satellite Accounts (TSA) and accounts from the System of Environmental-Economic Accounting (SEEA). While the TSA is a statistical standard developed with the aim of measuring the economic importance of tourism, SEEA is designed to extend current data monitoring and assessments beyond an economic focus, by integration of economic, environmental, and social data (UNWTO, 2004). This kind of integration could provide a single, coherent framework for holistic decision-making. Therefore, the MST Framework indicators were designed to bring practical assistance to tourism and destinations at relevant spatial levels: global; national; and sub-national, using some vital policy questions:

- environmental impacts of tourism-emissions, solid waste, wastewater, disruption of ecosystems and biodiversity;

- dependency of tourism on the environment-water and energy requirements, healthy and good quality ecosystems (beaches, reefs, forests);

- environmental protection expenditure and environmental taxes; and

- certain socio-economic impacts and dependencies of tourism such as employment (UNWTO, 2017).

These indicators have been piloted on different governance levels and geographical scopes in Austria, Canada, Fiji, Italy, Mexico, Netherlands, Philippines, Saudi Arabia, Sweden, and Wales. Furthermore, these indicators are a response to demand for high-quality indicators that monitor progress towards the SDGs 8, 12, and 14 (UNWTO \& OAS, 2018). Also, in order to catalyse changes in tourism operations using evidence-based efficiency and innovation and collaboration among wide range of stakeholders, the UNWTO has a global mandate to track the progress of the Sustainable Tourism Programme, which is constituent part of the 10Year Framework of Programmes on Sustainable Consumption and Production Patterns - 10 YFP (UNWTO, 2015).
$\mathrm{Da}$ bi se potaknulo usporedivo, integrirano i relevantno donošenje odluka, skup standardiziranih pokazatelja održivoga turizma razvijen je putem inicijativa, projekata ili uspostavom stručnih mehanizama izvještavanja. Jedan od najvažnijih setova pokazatelja održivoga turizma bio je prijedlog inicijative za Mjerni okvir održivoga turizma (MST Framework), koji je krajem 2015. započela Svjetska turistička organizacija UN-a (UNWTO) u suradnji sa statističkim odjelom UN-a (UNSD). Okvir MST-a sastojao se od satelitskih turističkih računa (TSA) i računa iz sustava ekološko-gospodarskoga računovodstva (SEEA). TSA je statistički standard razvijen s ciljem mjerenja gospodarske važnosti turizma, a SEEA je dizajnirana tako da proširi praćenje tekućih podataka i procjena izvan gospodarskoga interesa integracijom gospodarskih, ekoloških i socijalnih podataka (UNWTO, 2004). Takva vrsta integracije mogla bi osigurati jedinstven, koherentan okvir za cjelovito donošenje odluka. Stoga su okvirni pokazatelji MST-a osmišljeni kako bi se pružila praktična pomoć turizmu i destinaciji na relevantnim prostornim razinama: globalnim, nacionalnim i regionalnim putem nekih vitalnih pitanja politike, uključujući:

- utjecaj turizma na okoliš: emisije, kruti otpad, otpadne vode, poremećaj ekosustava i bioraznolikost

- ovisnost turizma o okolišu: potrebe za vodom i energijom, zdravi i kvalitetni ekosustavi (plaže, grebeni, šume)

- rashode za zaštitu okoliša i poreze na okoliš

- neke socioekonomske učinke i ovisnosti turizma kao što su zapošljavanje (UNWTO, 2017).

Ti su pokazatelji pilotirani u različitim razinama i opsegu u Austriji, Kanadi, Fidžiju, Italiji, Meksiku, Nizozemskoj, Filipinima, Saudijskoj Arabiji, Švedskoj i Walesu. Nadalje, ti bi pokazatelji trebali biti odgovor na potražnju za visokokvalitetnim pokazateljima koji prate napredak prema ciljevima održivoga razvoja 8, 12, 14 (UNWTO i OAS, 2018). Također, njihova uloga bit će i kataliziranje promjena u turizmu kroz učinkovitost i inovacije temeljene na dokazima i kroz suradnju širokoga spektra dionika. UNWTO ima globalni mandat pratiti napredak programa održivoga turizma koji je sastavni dio desetogodišnjega okvira Programa o održivoj potrošnji i obrascima proizvodnje - 10 YFP (UNWTO, 2015). 


\section{European Commission-European Tourism Indicators System}

According to Agenda for Sustainable and Competitive European Tourism (EC, 2007), the European Tourism Indicators System (ETIS) was developed in February 2013 to increase the sustainability and competitiveness of destinations in Europe. It is designed to be a voluntary tool for monitoring the progress of performance in sustainable tourism activities and to support policy creation for any destination. Therefore, ETIS influences legitimate political decisions and also increases value and the visitor experience, and raises public awareness of the need for tourism sustainability and behavioural changes on the part of all stakeholders in the sector.

In the period from 2013 to 2015, via a pilot initiative that was conducted in 108 destinations across Europe, practical use of ETIS was tested. In the end, 60 destinations completed the project implementation successfully. Implementation did not cover all European states, rather only the regions, provinces, protected areas and municipalities which decided to participate in the process: Bulgaria (9 municipalities and regions); Croatia (3 municipalities); Montenegro (1 municipality); Germany (5 municipalities); Greece (2 islands); Hungary (1 region); France (1 Municipality); Ireland (1 geopark); Italy (14 municipalities, regions and provinces); Montenegro (1 municipality); Slovenia (4 municipalities); Spain (8 municipalities and provinces); the UK (5 municipalities and regions), and the Netherlands (2 regions). These pilots resulted in valuable improvements to the ETIS, which have been incorporated into the 2016 edition of the ETIS toolkit (EC, 2016). Toolkit has shown that the most important characteristic of the ETIS system is the flexibility of various comprehensive sets of indicators. These indicators are grouped into four sections:

- destination management (sustainable tourism policies, tourism management in tourism enterprises, customer satisfaction, information and communication);

- social and cultural impact (impact on community/ society, gender equality, conservation and enhancement of cultural heritage, local identity and property);

- economic value (tourism traffic, business results of
Europska komisija - Europski sustav pokazatelja turizma

Prema Programu održivoga i konkurentnoga europskog turizma (EC, 2007) u veljači 2013. godine razvijen je Europski sustav pokazatelja turizma (ETIS) kako bi se povećala održivost i konkurentnost destinacija u Europi. Osmišljena je kao dragovoljno sredstvo za praćenje napretka u aktivnostima održivoga turizma i potporu kreiranju politika za bilo koju destinaciju. Stoga ETIS doprinosi utjecaju na legitimne političke odluke, ali i povećanju vrednovanja i iskustva posjetitelja te podizanju javne svijesti o potrebi održivosti turizma i promjeni ponašanja svih dionika u tom sektoru.

U razdoblju od 2013. do 2015. pilot-inicijativom provedenom na 108 destinacija diljem Europe testirana je praktična uporaba ETIS-a. $\mathrm{Na}$ kraju je 60 destinacija uspješno završilo provedbu projekta. Provedba nije obuhvatila sve europske države, već regije, pokrajine, zaštićena područja i jedinice lokalne samouprave (JLS) koje su odlučile sudjelovati u procesu: Bugarska (9 JLS i regija), Hrvatska (3 JLS), Crna Gora (1 JLS), Njemačka (5 JLS), Grčka (2 otoka), Mađarska (1 regija), Francuska (1 JLS), Irska (1 geopark), Italija (14 JLS-a, regija i pokrajina), Crna Gora (1 JLS), Slovenija (4 JLS), Španjolska (8 JLS-a i provincija), Ujedinjeno Kraljevstvo (5 JLS-a i regija) i Nizozemska (2 regije). Ti su piloti dali prema povratnim informacijama iz destinacija vrijedna poboljšanja ETIS-a, koja su i uključena u novo izdanje ETIS priručnika iz 2016. godine (EC, 2016). U priručniku se navodi da je važno obilježje sustava ETIS-a fleksibilnost različitih, ali sveobuhvatnih skupina pokazatelja, grupiranih u četiri odjeljka:

- upravljanje destinacijom (politike održivoga turizma, upravljanje turizmom u turističkim poduzećima, zadovoljstvo korisnika, informiranje i komunikacija)

- gospodarski učinci (turistički tokovi, poslovni rezultati turističkih poduzeća, količina i kvaliteta zaposlenosti, sigurnost i zdravlje, turistički opskrbni lanac)

- društveni/kulturni utjecaji (utjecaj na zajedni-
I. Marković Vukadin M. Zovko

D. Krešić

Review and evaluation of existing international systems of tourism sustainability indicators

Pregled i evaluacija postojećih

međunarodnih sustava pokazatelja održivosti turizma 
tourism enterprises, quantity and quality of employment, safety and health, tourism supply chain); and

- environmental impacts (reduction the of impact from the energy and traffic sectors, mitigation of and adaptation to climate change, sustainable waste management, wastewater treatment, water management, landscape and biodiversity protection, light and noise pollution, and achieving satisfactory water quality for swimming) (EC, 2016).

Today, the ETIS system contains 43 essential core indicators that cover the fundamental aspects of sustainability monitoring of a destination, and supplementary indicators for collecting additional information that are tailored to the particular type or category of destination or tourism market (EC, 2016). It is important to stress that ETIS indicators allow for comparison and benchmarking between destinations over time, and thus serve to improve the competitive position of Europe as tourist destination.

\section{Organisation for Economic Co-operation and Development indicators}

To foster analysis of tourism competitiveness and to inform tourism policy development about progress in the tourism market, the Organisation for Economic Co-operation and Development (OECD) created the guide and toolkit: Indicators for Measuring Competitiveness in Tourism: A Guidance Document (Dupeyras and McCollum, 2013). Using the TSA Framework, the OECD established the set of indicators, composed of three types-core, supplementary, and indicators for future development. In order to monitor and measure tourism competitiveness, economic market results, and relative changes, the 11 core indicators and a further 9 additional indicators have been organised in four categories:

- tourism performance and impacts;

- ability of a destination to deliver quality and competitive tourism services;

- attractiveness of a destination; and

- policy responses and economic opportunities (Dupeyras and McCollum, 2013). cu/društvo, ravnopravnost spolova, zaštita i jačanje kulturnoga nasljeđa, lokalnoga identiteta $\mathrm{i}$ imovine) te

- zaštita okoliša/prirode (smanjenje utjecaja prometa, klimatske promjene, gospodarenje otpadom, obrada otpadnih voda, gospodarenje vodom, potrošnja energije, zaštita krajolika i bioraznolikosti, onečišćenje svjetlošću i bukom i kvaliteta vode za kupanje (EC, 2016).

Danas sustav ETIS-a sadrži 43 bazna pokazatelja koji obuhvaćaju temeljne aspekte praćenja održivosti destinacija te dodatne pokazatelje za prikupljanje dodatnih informacija prilagođenih za pojedinu vrstu ili kategoriju destinacije ili turističkoga tržišta (EC, 2016). Važno je naglasiti da ETIS pokazatelji omogućuju usporedbu referentnih vrijednosti između destinacija tijekom vremena, čime se omogućuje provedba konkurentnoga položaja Europe kao turističke destinacije.

\section{Sustav pokazatelja Organizacije za ekonomsku suradnju i razvoj}

Prepoznajući turizam kao jedan od ključnih sektora razvoja za velik broj zemalja te, ujedno, svjesna sporadične i neujednačene prakse u praćenju njegovih utjecaja, Organizacija za ekonomsku suradnju i razvoj (OECD) razvila je međunarodno primjenjiv i usporediv sustav pokazatelja za mjerenje konkurentnosti turizma kao relevantnoga alata u donošenju nacionalnih turističkih politika (Dupeyras i MacCallum, 2013). Uzimajući u obzir pitanja s kojima se suočava okvir TSA, OECD je utvrdio skup pokazatelja koji se sastoje od tri vrste pokazatelja ključnih, dopunskih i pokazatelja za budući razvoj. U cilju praćenja i mjerenja konkurentnosti turizma, rezultata na gospodarskom tržištu i relativnih promjena 11 osnovnih pokazatelja i dodatnih 9 pokazatelja organizirano je u četiri kategorije:

- rezultati i utjecaji razvoja turizma

- sposobnost destinacije da pruža kvalitetne i konkurentne turističke usluge

- atraktivnost destinacije

- odgovor politike i gospodarske prilike (Dupeyras i McCollum, 2013). 
Although the measurement of touristic competitiveness is a priority area, the OECD set of indicators are intended to capture the environmental component as part of destination's attractiveness, as well as education for those employed in the sector-which remains a constant economic and social challenge.

\section{Global Sustainable Tourism Council indicators}

To develop global standards for sustainable travel and tourism for operators and hotels, the Global Sustainable Tourism Council (GSTC) developed the GSTC Criteria in 2013, with a clear vision to preserve natural and cultural resources and alleviate poverty while ensuring that tourism develops (GSTC, 2013a). The GSTC's Criteria for public policy-makers and destination managers, and industry criteria for hotels and tour operators are strongly linked to United Nations Sustainable Development Goals (SDGs) with four main objectives:

- to demonstrate sustainable destination management;

- to maximise social and economic benefits for the host community and to minimise negative impacts;

- to maximise benefits to communities, visitors, and cultural heritage and to minimise impacts; and

- to maximise benefits to the environment and minimise negative impacts (GSTC, 2013b).

Due to the fact that public sector tourism policy-makers and destination managers consider sustainability in their practices with interdisciplinary, holistic, and integrative approaches, the GSTC provided criteria for destinations and performance indicators. These criteria are based on economic, environmental, and social dimensions, and are designed to be used by all types and scales of destinations. One of the focuses of this indicator system is to obtain one of three green certificates (Green Globe, EarthCheck and Vireo Srl). Destinations certified based on applying this indicator systems include Botswana, Cayman Islands, the City of Suwon and Ulsan Metropolitan City (South Korea), Guatemala, Norway, Japan, Malta, Mount Huangshan Scenic Area (China), the Västerbotten Region (Sweden), Saint Kitts and Nevis, Taiwan, Barcelona (Spain), and Vanuatu.
Iako je mjerenje turističke konkurentnosti prioritetno područje ovoga sustava pokazatelja, OECD skup pokazatelja kreiran je i da obuhvati stanje okolišne komponente prostora kao dijela privlačnosti destinacije kao i obrazovanja za zaposlenike u tom sektoru, što ostaje stalan gospodarski, ali i društveni izazov.

\section{Sustav pokazatelja Globalnoga vijeća za održivi turizam}

Kako bi se razvili globalni standardi za održivo putovanje i turizam za operatere i hotele, Globalno vijeće za održivi turizam (GSTC) razvilo je 2013. godine GSTC kriterije s jasnom vizijom očuvanja prirodnih i kulturnih resursa i ublažavanja siromaštva uz istovremeno osiguravanje zadovoljstva turista (GSTC, 2013a). GSTC kriteriji za kreatore javnih politika i upravitelje destinacija te sektorski kriteriji za hotele i turoperatore snažno su povezani s ciljevima održivoga razvoja Ujedinjenih naroda s četiri glavna cilja:

- uspostaviti održivo upravljanje destinacijom

- maksimizirati društvene i gospodarske koristi za zajednicu domaćina i minimizirati negativne učinke

- maksimizirati koristi za zajednice, posjetitelje i kulturnu baštinu te minimizirati utjecaje

- maksimizirati prednosti za okoliš i smanjenje negativnih utjecaja (GSTC, 2013b).

Zbog činjenice da kreatori turističkih politika i voditelji destinacija u javnom sektoru smatraju održivost u svojim praksama interdisciplinarnim, holističkim i integrativnim pristupom GSTC je iznio kriterije za destinacije i pokazatelje uspješnosti. Ti se kriteriji temelje na ekonomskim, okolišnim i socijalnim dimenzijama, a osmišljeni su da se njima koriste sve vrste i veličine destinacija. Jedan od fokusa ovoga sustava pokazatelja jest steći jedan od tri zelena certifikata (Green Globe, EarthCheck i Vireo Srl). Destinacije certificirane na temelju primjene toga sustava su Bocvana, Kajmanski otoci, Grad Suwon i Ulsan Metropolitan City (Južna Koreja), Gvatemala, Norveška, Japan, Malta, Mount Huangshan (Kina), Regija Västerbotten (Švedska), Sveti Kristofor i Nevis, Tajvan, Barcelona (Španjolska) i Vanuatu.
I. Marković Vukadin M. Zovko

D. Krešić

Review and evaluation of existing international systems of tourism sustainability indicators

Pregled i evaluacija postojećih

međunarodnih sustava pokazatelja održivosti turizma 
GEOGRAFSKI

GLASNIK

82/1, 85-110 (2020.)

\section{Other international initiatives and projects}

In 2013, European Environment Agency (EEA) began to develop an indicator-based reporting mechanism TOUERM - Tourism and Environment Reporting Mechanism (Tab. 1). The main scope of this project was to identify monitoring and reduction modes of tourism sectoral pressures to the environment from variety of sources. To gain a more comprehensive picture of tourism in parallel with evidence-based measurement derived from the environmental performance of several distinct European economic sectors (Giulietti et al., 2016) - i.e. transport, energy, agriculture, and industry the EEA provided the TOUREM set of indicators and data analysis. Furthermore, this reporting mechanism meets the demands of the Seventh Environment Action Programme "Living well, within the limits of our planet" (EEA, 2013a), and more specifically, the demands of the "EEA multiannual work programme 2014-2020", which foresees the development of data sets and indicators to track sustainability trends and the environmental and territorial impacts of economic sectors that depend on land use, such as tourism (EEA, 2013b). Therefore, this project systematically explored and identified:

- the policy relevance of TOUERM as a reporting framework;

- connections between tourism and environment in Europe; and

- the main topics and indicators that can address them (EEA, 2018).

The indicators were developed according to: i) data availability; ii) methodology; iii) processing; iv) policy relevance; and v) clarity of the message. The indicators are also assessed in the cause-effect chain of DriversPressures-State-Impacts-Responses (the so-called DPSIR analytical framework), which is used as the standard EEA model to analyse interactions between society and the environment (EEA, 2018). Finally, of the 25 priority data sets identified, 19 have been developed to produce TOUREM indicators in order to cover a wide range of tourism-related aspects taking into account current practices, e.g. ETIS.

In addition to the above initiatives, there are a number of international initiatives that are largely methodologically based on the aforementioned systems, which are summarised in Tab. 1 .

\section{Druge međunarodne inicijative i projekti}

Europska agencija za okoliš (EEA) započela je 2013. razvijati mehanizam izvještavanja TOUERM - Mehanizam izvještavanja o turizmu i okolišu (tab. 1). Glavni cilj ovoga projekta bio je utvrditi načine praćenja i redukcije turističkih sektorskih pritisaka na okoliš iz različitih izvora. Kako bi se dobila sveobuhvatnija slika turizma usporedno s mjerenjem utemeljenim na dokazima koje proizlazi iz ekološke učinkovitosti nekoliko različitih europskih gospodarskih sektora (Giulietti i dr., 2016), odnosno prijevoza, energije, poljoprivrede i industrije, EEA pruža TOUREM skup pokazatelja i analizu podataka. Nadalje, ovaj mehanizam izvještavanja ispunjava zahtjeve Sedmoga programa djelovanja za okoliš „Živjeti dobro, unutar granica našeg planeta” (EEA, 2013a), odnosno zahtjeve „Višegodišnjega programa rada EGP-a 2014. - 2020.”, kojim se predviđa razvoj skupova podataka i pokazatelja za praćenje kretanja održivosti te okolišnih i teritorijalnih učinaka gospodarskih sektora ovisnih o korištenju zemljišta kao što je turizam (EEA, 2013b). Stoga je ovaj projekt sustavno istraživao i identificirao:

- politički značaj TOUERM-a kao izvještajnoga okvira

- povezanost turizma i okoliša u Europi

- glavne teme i pokazatelje koji ih mogu rješavati (EEA, 2018).

Pokazatelji su razvijeni s obzirom na: i) raspoloživost podataka, ii) metodologiju, iii) obradu podataka, iv) relevantnost politike i v) jasnoću poruke. Pokazatelji se također procjenjuju u lancu uzročnih učinaka pokretača i pritisaka - odgovora na državne utjecaje, tzv. analitičkoga okvira DPSIR-a, koji se upotrebljava kao standardni model EEA-a za analizu interakcija između društva i okoliša (EEA, 2018). Konačno, od 25 utvrđenih prioritetnih skupova podataka, 19 je razvijeno za izradu TOUREM pokazatelja kako bi se obuhvatio širok raspon aspekata povezanih s turizmom, uzimajući u obzir trenutačne prakse, npr. ETIS.

Osim navedenih inicijativa, postoji niz međunarodnih inicijativa koje se uglavnom metodološki temelje na prethodno objašnjenim inicijativama, a sažete su u tab. 1. 
Tab. 1 International initiatives aimed at monitoring the sustainability of tourism

I. Marković Vukadin

M. Zovko

D. Krešić

Tab. 1. Međunarodne inicijative usmjerene na praćenje održivosti turizma

\begin{tabular}{|c|c|c|c|}
\hline $\begin{array}{l}\text { Initiative / } \\
\text { Naziv } \\
\text { inicijative }\end{array}$ & $\begin{array}{l}\text { Management } \\
\text { body/ } \\
\text { Upravljačko } \\
\text { tijelo }\end{array}$ & $\begin{array}{l}\text { Objective / } \\
\text { Cilj }\end{array}$ & $\begin{array}{l}\text { Initiatives applied in destinations/regions / } \\
\text { Inicijative primijenjene u destinacijama }\end{array}$ \\
\hline $\begin{array}{l}\text { Tourism and } \\
\text { Environment } \\
\text { Reporting } \\
\text { Mechanism } \\
\text { (TOUERM) }\end{array}$ & $\begin{array}{l}\text { European } \\
\text { Environmental } \\
\text { agency - EEA / } \\
\text { Europska } \\
\text { okolišna agencija } \\
\text { - EEA }\end{array}$ & $\begin{array}{l}\text { Based on the use of relevant, feasible and regularly } \\
\text { updated indicators, the aim is to recognise the im- } \\
\text { pact of tourism on the environment and sustainability } \\
\text { trends in European counties./ } \\
\text { Na temelju korištenja relevantnih, izvedivih i redovito } \\
\text { ažuriranih pokazatelja cilj je prepoznavanje utjecaja } \\
\text { turizma na okoliš i trendova održivosti. }\end{array}$ & $\begin{array}{l}\text { EEA's member and cooperating countries*; e.g. Aus- } \\
\text { trian Alpine region, Mediterranean coastal region of } \\
\text { Spain, France, Italy and Croatia, etc./ } \\
\text { Članice i suradničke zemlje EEA-e; npr. austrijska } \\
\text { alpska regija, mediteranske obalne regije Španjolske, } \\
\text { Francuske, Italije i Hrvatske, itd. }\end{array}$ \\
\hline $\begin{array}{l}\text { International } \\
\text { Network of } \\
\text { Sustainable } \\
\text { Tourism } \\
\text { Observatories } \\
\text { (INSTO) }\end{array}$ & $\begin{array}{l}\text { United Nations } \\
\text { World tourism } \\
\text { organization - } \\
\text { UNWTO / } \\
\text { Svjetska } \\
\text { turistička } \\
\text { organizacija - } \\
\text { UNWTO }\end{array}$ & $\begin{array}{l}\text { The main objective is to support continuous im- } \\
\text { provement of sustainability in the tourism sector via } \\
\text { systematic, timely and regular monitoring of tourism } \\
\text { performance and impact, including connectivity of } \\
\text { destinations. It is dedicated to better understanding of } \\
\text { resource usage at the destination level, with the aim of } \\
\text { encouraging responsible tourism management. / } \\
\text { Glavni je cilj poduprijeti kontinuirano poboljšnje } \\
\text { održivosti u turističkom sektoru sustavnim, pravo- } \\
\text { dobnim i redovitim pracenjem uspješnosti i utjecaja } \\
\text { turizma te povezivanjem destinacija kako bi se bolje } \\
\text { razumjelo korištenje resursa u cijeloj destinaciji i po- } \\
\text { taknulo odgovorno upravljanje turizmom. }\end{array}$ & $\begin{array}{l}\text { Aegean Islands (Greece), Navarre (Spain), Bue- } \\
\text { nos Aires (Argentina), Antigua (Guatemala), Siem } \\
\text { Reap (Cambodia), Southwest Australia (Australia), } \\
\text { Thompson Okanagan (Canada), the City of Mali } \\
\text { Lošinj, and the wider region of seven coastal Adriatic } \\
\text { counties (Croatia), etc./ } \\
\text { Egejski otoci (Grčka), Navarra (Španjolska), Buenos } \\
\text { Aires (Argentina), Antigva (Gvatemala), Siem Reap } \\
\text { (Kambodža), regija Jugozapadna Australija (Austra- } \\
\text { lija), Thompson Okanagan (Kanada), Grad Mali Lo- } \\
\text { šinj i Jadranska Hrvatska, itd. }\end{array}$ \\
\hline $\begin{array}{l}\text { International } \\
\text { Network on } \\
\text { Regional } \\
\text { Economics, } \\
\text { Mobility } \\
\text { and Tourism } \\
\text { (INRouTe) }\end{array}$ & $\begin{array}{l}\text { United Nations } \\
\text { World tourism } \\
\text { organization - } \\
\text { UNWTO / } \\
\text { Svjetska } \\
\text { turistička } \\
\text { organizacija - } \\
\text { UNWTO }\end{array}$ & $\begin{array}{l}\text { An initiative dedicated to improving policy-oriented } \\
\text { tourism measurement and analysis, to provide ope- } \\
\text { rational guidance to bodies and experts involved in } \\
\text { regional and sub-regional administrations. / } \\
\text { Inicijativa posvećena unaprjeđenju mjerenja i anali- } \\
\text { ze turizma usmjerenih na politiku kako bi se pružile } \\
\text { operativne smjernice tijelima i stručnjacima uključe- } \\
\text { nim u regionalne i subregionalne uprave. }\end{array}$ & $\begin{array}{l}\text { Tuscany Region (Italy), Sacatepequez (Guatemala), } \\
\text { La Rioja, Bilbao, Navarre, Euskadi, Canary Islands, } \\
\text { Basque Country (Spain), Almaty (Kazakhstan) / } \\
\text { Toskana (Italija), Sacatepequez (Gvatemala), La Rio- } \\
\text { ja, Bilbao, Navarra, Euskadi, Kanarski otoci, Baskija } \\
\text { (Španjolska), Almaty (Kazahstan) }\end{array}$ \\
\hline $\begin{array}{l}\text { Network of Eu- } \\
\text { ropean Regions } \\
\text { for Sustainable } \\
\text { and Compet- } \\
\text { itive Tourism } \\
\text { (NECSTouR) }\end{array}$ & $\begin{array}{l}\text { European } \\
\text { regions / } \\
\text { Europske regije }\end{array}$ & $\begin{array}{l}\text { An initiative that implements the ten principles of } \\
\text { the Agenda for Sustainable and competitive Europe- } \\
\text { an Tourism, and has a special working group dedica- } \\
\text { ted to providing tourism indicators. / } \\
\text { Provodi deset načela Agende za održivi i konkurentni } \\
\text { europski turizam, a ima posebnu radnu skupinu po- } \\
\text { svećenu turističkim pokazateljima. }\end{array}$ & $\begin{array}{l}\text { Madeira (Portugal), the City of Hamburg (Germany), } \\
\text { Kaunas (Lithuania), Rethymno (Greece), the Galicia } \\
\text { Region (Spain), the Municipality of Rome (Italy)/ } \\
\text { Madeira (Portugal), Hamburg (Njemačka), Kaunas } \\
\text { (Litva), Retimno (Grčka) Galicija (Španjolska), Rim } \\
\text { (Italija) }\end{array}$ \\
\hline $\begin{array}{l}\text { European } \\
\text { Charter for } \\
\text { Sustainable } \\
\text { Tourism in } \\
\text { Protected Areas } \\
\text { (ECST). }\end{array}$ & $\begin{array}{l}\text { EUROPARC } \\
\text { federation / } \\
\text { Europska } \\
\text { federacija } \\
\text { zaštićenih } \\
\text { područja - } \\
\text { EUROPARC }\end{array}$ & $\begin{array}{l}\text { A management tool to ensure that tourism contri- } \\
\text { butes to balanced economic, social, and environmen- } \\
\text { tal development in protected areas in Europe. The } \\
\text { focus is on destinations, local companies, and tour } \\
\text { operators./ } \\
\text { To je upravljački alat kojim se osigurava da turizam } \\
\text { pridonosi uravnoteženom gospodarskom, društve- } \\
\text { nom i ekološkom razvoju zaštićenih područja u Eu- } \\
\text { ropi. Fokus je na destinacijama, lokalnim tvrtkama i } \\
\text { organizatorima putovanja. }\end{array}$ & $\begin{array}{l}\text { Plitvice Lakes National Park (Croatia), Park Jura } \\
\text { (Switzerland), Thayatal National Park (Austria), Vat- } \\
\text { najökull National Park (Iceland), Grenoble-Alpes } \\
\text { Metropole (France), etc. / } \\
\text { Nacionalni park Plitvička jezera (Hrvatska), Nacio- } \\
\text { nalni park Jura (Švicarska), Nacionalni park Thayatal } \\
\text { (Austrija), Nacionalni park Vatnajökull (Island), Gre- } \\
\text { noble-Alpes (Francuska), itd. }\end{array}$ \\
\hline $\begin{array}{l}\text { European } \\
\text { network for } \\
\text { sustainable } \\
\text { tourism } \\
\text { development, } \\
\text { Ecotrans }\end{array}$ & $\begin{array}{l}\text { Various } \\
\text { organisations / } \\
\text { Veći broj } \\
\text { organizacija }\end{array}$ & $\begin{array}{l}\text { Encourages monitoring sustainability via exchanges } \\
\text { of experience and knowledge among the members, as } \\
\text { well as via global networking, support, and contribu- } \\
\text { tion to joint projects./ } \\
\text { Potiče na praćenje održivosti kroz razmjenu iskusta- } \\
\text { va i znanja sa svojim članovima, kao i kroz globalno } \\
\text { umrežavanje, potporu i doprinos zajedničkim projek- } \\
\text { tima. }\end{array}$ & $\begin{array}{l}\text { Tourist Green Resort Garden Village Bled (Slove- } \\
\text { nia), Nin (Croatia), Silesian Region (Poland), Oeste } \\
\text { Region (Portugal), } \\
\text { Noordwijk (Netherlands), } \\
\text { Migliarino San Rossore (Italy) / } \\
\text { Turistički resort Garden Village Bled (Slovenija), Nin } \\
\text { (Hrvatska), Šleska regija (Poljska), Oeste (Portugal), } \\
\text { Noordwijk (Nizozemska), } \\
\text { Migliarino San Rossore (Italija) }\end{array}$ \\
\hline
\end{tabular}

Review and evaluation of existing international systems of tourism sustainability indicators

Pregled i evaluacija postojećih međunarodnih sustava pokazatelja održivosti turizma 
GEOGRAFSKI

GLASNIK

82/1, 85-110 (2020.)
Tab. 2 Selected EU projects aimed at developing destination indicators

Tab. 2. Odabrani EU projekti s fokusom na razvoj destinacijskih pokazatelja

\begin{tabular}{|c|c|c|c|}
\hline $\begin{array}{l}\text { Project / } \\
\text { Projekt }\end{array}$ & $\begin{array}{l}\text { Project objective / } \\
\text { Cilij projekta }\end{array}$ & $\begin{array}{l}\text { Indicators / } \\
\text { Pokazatelji }\end{array}$ & $\begin{array}{l}\text { Project applied in destinations/regions / } \\
\text { Projekti implementirani u destinacijama }\end{array}$ \\
\hline CO-EVOLVE & $\begin{array}{l}\text { It analyses and promotes co-evolution } \\
\text { of human activities and natural sys- } \\
\text { tems in coastal tourist areas and con- } \\
\text { nects currently unavailable analysis at } \\
\text { the level of the Mediterranean, as well } \\
\text { as threats, and factors that relate to } \\
\text { sustainable tourism./ } \\
\text { Analizira i promiče koevoluciju ljud- } \\
\text { skih aktivnosti i prirodnih sustava u } \\
\text { turističkim obalnim područjima i pov- } \\
\text { ezuje trenutno nedostupnu analizu na } \\
\text { razini Mediterana, prijetnje i čimbeni- } \\
\text { ke koji omogućuju održivi turizam. }\end{array}$ & $\begin{array}{l}\text { Specific indicators for representative } \\
\text { Pilot areas evaluating sustainability } \\
\text { in terms of criteria corresponding to } \\
\text { four dimensions (environment, society, } \\
\text { economy, and governance)./ } \\
\text { Specifični pokazatelji za reprezentativ- } \\
\text { na pilot-područja koja ocjenjuju održi- } \\
\text { vost u smislu kriterija koji odgovaraju } \\
\text { četirima dimenzijama (okoliš, društvo, } \\
\text { ekonomija i upravljanje). }\end{array}$ & $\begin{array}{l}\text { The East Macedonia and Thrace regions } \\
\text { (Greece), Veneto Delta Po Park (Italy), Valencia } \\
\text { (Spain), Hérault (France), Kaštela Bay and Ner- } \\
\text { etva Delta (Croatia)/ } \\
\text { Regija Istočna Makedonija i Trakija (Grčka), } \\
\text { Park Veneto Delta Po (Italija), Valencija (Špa- } \\
\text { njolska), Hérault (Francuska), Kaštelanski zaljev } \\
\text { i delta Neretve (Hrvatska) }\end{array}$ \\
\hline MITOMED+ & $\begin{array}{l}\text { It deals with the lack of knowledge } \\
\text { regarding tourist data by testing, } \\
\text { transferring, and capitalising on an } \\
\text { integrated management system where } \\
\text { indicators are improved in terms of } \\
\text { coverage, sector, quality and resolu- } \\
\text { tion./ } \\
\text { Bavi se nedostatkom znanja o turi- } \\
\text { stičkim podatcima testiranjem, prije- } \\
\text { nosom i kapitalizacijom integriranoga } \\
\text { sustava upravljanja u kojem su pokaza- } \\
\text { telji poboljšani u smislu pokrivenosti, } \\
\text { sektora, kvalitete i rezolucije. }\end{array}$ & $\begin{array}{l}\text { The project is developing a set of in- } \\
\text { dicators built on the ETIS manual, } \\
\text { designed to be applied in coastal des- } \\
\text { tinations./ } \\
\text { Projekt razvija skup pokazatelja koji se } \\
\text { grade na ETIS-u priručniku koji će se } \\
\text { primjenjivati u obalnim destinacijama. }\end{array}$ & $\begin{array}{l}\text { Andalusia and Catalonia (Spain), Cyprus, Istria } \\
\text { (Croatia), Tuscany (Italy)/ } \\
\text { Andaluzija i Katalonija (Španjolska), Cipar, Istra } \\
\text { (Hrvatska), Toskana (Italija) }\end{array}$ \\
\hline ShapeTourism & $\begin{array}{l}\text { It aims to improve the knowledge } \\
\text { framework regarding tourism by pro- } \\
\text { viding analyses and operational tools } \\
\text { to define an integrated methodology, } \\
\text { which will foster sustainable tourism } \\
\text { growth, especially for cultural desti- } \\
\text { nations./ } \\
\text { Cilj je pobolǰsati okvir znanja o turiz- } \\
\text { mu pružajući analize i operativne alate } \\
\text { kako bi se odredila integrirana meto- } \\
\text { dologija temeljem koje će se potaknuti } \\
\text { održivi rast turizma, posebno za kul- } \\
\text { turne destinacije. }\end{array}$ & $\begin{array}{l}\text { The project focuses on indicators and } \\
\text { is developing a set of tools-in par- } \\
\text { ticular a smart integrated tourism data } \\
\text { system (SITDS). It uses innovative } \\
\text { statistical sources, directly taken from } \\
\text { the internet and mobile phones. / } \\
\text { Projekt se fokusira na pokazatelje i } \\
\text { razvija skup alata, osobito pametnoga } \\
\text { integriranog sustava podataka o turiz- } \\
\text { mu (SITDS). Koristi se inovativnim } \\
\text { statističkim izvorima izravno s inter- } \\
\text { neta/mobilnoga telefona. }\end{array}$ & $\begin{array}{l}\text { Veneto Region (Italy), Split-Dalmatia County } \\
\text { (Croatia), Cyprus, Algavre (Portugal), Malaga } \\
\text { (Spain)/ } \\
\text { Regija Veneto (Italija), Splitsko-dalmatinska } \\
\text { županija (Hrvatska), Cipar, Algarve (Portugal), } \\
\text { Malaga (Spanjolska) }\end{array}$ \\
\hline ALTER ECO & $\begin{array}{l}\text { The aim is to implement alternative } \\
\text { tourism strategies that enable sustain- } \\
\text { able development of local tourism by } \\
\text { promoting Mediterranean identity./ } \\
\text { Cilj je provedba alternativnih turistič- } \\
\text { kih strategija koje omogućuju održivi } \\
\text { razvoj lokalnoga turizma promicanjem } \\
\text { Mediteranskoga identiteta. }\end{array}$ & $\begin{array}{l}\text { Application of ETIS in Pilot areas./ } \\
\text { Primjena ETIS-a na pilot-područjima. }\end{array}$ & $\begin{array}{l}\text { Dubrovnik (Croatia), Genoa and Veneto (Italy), } \\
\text { Malaga (Spain), Comunitat Valenciana (Spain), } \\
\text { South Aegean region (Greece) / } \\
\text { Dubrovnik (Hrvatska), Genova i Venecija, (Ita- } \\
\text { lija), Malaga (Španjolska), Valencijska zajednica } \\
\text { (Şpanjolska), regija Južni Egej (Grčka) }\end{array}$ \\
\hline
\end{tabular}




\begin{tabular}{|c|c|c|c|}
\hline $\begin{array}{l}\text { Project / } \\
\text { Projekt }\end{array}$ & $\begin{array}{l}\text { Project objective / } \\
\text { Cilj projekta }\end{array}$ & $\begin{array}{l}\text { Indicators / } \\
\text { Pokazatelji }\end{array}$ & $\begin{array}{l}\text { Project applied in destinations/regions / } \\
\text { Projekti implementirani u destinacijama }\end{array}$ \\
\hline BLUEMED & $\begin{array}{l}\text { It aims to evaluate the underwater } \\
\text { heritage of the Mediterranean by } \\
\text { planning, testing and coordinating un- } \\
\text { derwater museums, diving parks, and } \\
\text { centres to raise awareness of the im- } \\
\text { portance of the environment. / } \\
\text { Nastoji valorizirati podvodnu baštinu } \\
\text { Mediterana planiranjem, testiranjem } \\
\text { i koordiniranjem podvodnih muzeja, } \\
\text { ronilačkih parkova i centara za podi- } \\
\text { zanje svijesti o važnosti okoliša. }\end{array}$ & $\begin{array}{l}\text { Key performance indicators for me- } \\
\text { asurement are used in the project to } \\
\text { assess the impact of the proposed } \\
\text { activities on the natural, cultural, and } \\
\text { economic environment. / } \\
\text { U projektu su korišteni ključni poka- } \\
\text { zatelji uspješnosti za mjerenje utjecaja } \\
\text { predloženih aktivnosti na prirodno, } \\
\text { kulturno i gospodarsko okruženje. }\end{array}$ & $\begin{array}{l}\text { Capo Rizutto (Italy), Baia Bay (Italy), Western } \\
\text { Pagasitikos/Sporades; Peristera, Alonnisos } \\
\text { (Greece), Cavtat (Croatia)/ } \\
\text { Capo Rizzuto (Italija), zaljev Baia (Italija), za- } \\
\text { padni Pagasitikos / Sporadi; Peristera, Alonnisos } \\
\text { (Grčka), Cavtat (Hrvatska) }\end{array}$ \\
\hline DestiMED & $\begin{array}{l}\text { The project aims to encourage the } \\
\text { planning, management, monitoring, } \\
\text { and promotion of eco-tourism in } \\
\text { Mediterranean protected areas./ } \\
\text { Cilj je projekta poticanje planiranja, } \\
\text { upravljanja, praćenja i promicanja eko- } \\
\text { turizma na mediteranskim zaštićenim } \\
\text { područjima. }\end{array}$ & $\begin{array}{l}\text { The project is testing the establish- } \\
\text { ment of a system for monitoring the } \\
\text { sustainability of eco-tourism products } \\
\text { and setting standards for "Mediterra- } \\
\text { nean eco-tourism destinations”, based } \\
\text { on previous experiences./ } \\
\text { Projekt testira uspostavu sustava za } \\
\text { praćenje održivosti ekoturističkih pro- } \\
\text { izvoda i postavljanje standarda "Me- } \\
\text { diteranske ekoturističke destinacije" } \\
\text { temeljem prijašnjih iskustava. }\end{array}$ & $\begin{array}{l}\text { Samaria National Park (Greece), Lastovo Islands } \\
\text { Nature Park and Kornati National Park (Croa- } \\
\text { tia), Circeo National Park, Torre del Cerrano } \\
\text { Marine Protected Area and Riviera di Ulisse Re- } \\
\text { gional Park (Italy), S'Albufera des Grau Natural } \\
\text { Park, Menorca and Ebro Delta Natural Park } \\
\text { and Colline Metallifere Natural Park (Spain), } \\
\text { Camargue Nature Park and Calanques National } \\
\text { Park (France), Shkodra Region and Vlora Regi- } \\
\text { on (Albania)/ } \\
\text { Nacionalni park Samaria (Grčka), Park priro- } \\
\text { de Lastovsko otočje i Nacionalni park Kornati } \\
\text { (Hrvatska), Nacionalni park Circeo, Zaštićeno } \\
\text { morsko područje Torre del Cerrano i Regional- } \\
\text { ni park Riviera di Ulisse (Italija), Prirodni park } \\
\text { S'Albufera des Grau, Menorca i Ebro Prirodni } \\
\text { park Delta i prirodni park Colline Metallifere } \\
\text { (Španjolska), Park prirode Camargue i Nacio- } \\
\text { nalni park Calanques (Francuska), Regije Skadar } \\
\text { i Vlora (Albanija) }\end{array}$ \\
\hline CEETO & $\begin{array}{l}\text { The project aims to transfer knowledge } \\
\text { and develop guidelines for the devel- } \\
\text { opment of eco-tourism in Central } \\
\text { Europe / } \\
\text { Projekt je usmjeren na transfer znanja } \\
\text { i oblikovanje smjernica za razvoj eko- } \\
\text { turizma u Srednjoj Europi. }\end{array}$ & $\begin{array}{l}\text { It focuses on the design of governance } \\
\text { indicators for the improvement of pro- } \\
\text { tected area policies./ } \\
\text { Usmjereno je na oblikovanje uprav- } \\
\text { ljačkih pokazatelja za unaprjeđenje } \\
\text { politika zaštićenih područja. }\end{array}$ & $\begin{array}{l}\text { Regional Park of the Po Delta, Alto Appenni- } \\
\text { no Modenese Regional Park, Appennino Tosco } \\
\text { Emiliano National Park, Nirano's Mud Volca- } \\
\text { noes Nature Reserve (Italy), Söelktäler Nature } \\
\text { Park, UNESCO Biosphere Reserve Salzburger } \\
\text { Lungau (Austria), UNESCO Biosphere Reser- } \\
\text { ve Southeast Ruegen (Germany), Medvednica } \\
\text { Nature Park (Croatia), Strunjan Landscape Park } \\
\text { (Slovenia) / } \\
\text { Appennino Modenese, Nacionalni park Appe- } \\
\text { nino Tosco Emiliano, Prirodni rezervat Nudano } \\
\text { blatni vulkani (Italija), Park prirode Söelktäler, } \\
\text { Rezervat biosfere UNESCO-a Salzburger Lun- } \\
\text { gau (Austrija), Rezervat biosfere UNESCO-a } \\
\text { Jugoistočni Ruegen (Njemačka), Park prirode } \\
\text { Medvednica (Hrvatska), Pejzažni park Strunjan } \\
\text { (Slovenija) }\end{array}$ \\
\hline
\end{tabular}

Review and evaluation of existing international systems of tourism sustainability indicators

Pregled i evaluacija postojećih međunarodnih sustava pokazatelja održivosti turizma

Source: authors, according to Interreg Mediterranean Programme (2020) and Interreg Central Europe Programme (2020) Izvor: autori prema: Interreg Mediterranean programme (2020) i Interreg Central Europe programme (2020) 
The need and desire of the European Commission to make Europe a viable destination has contributed to the development of a large number of EU projects in the search for focused indicators. Some of the more prominent ones are described below.

To preserve rich natural and cultural heritage and to promote Mediterranean resources, the transnational project "MITOMED - Models of Integrated TOurism in the MEDiterranean" was implemented from 2014 to 2015. Taking into account MITOMED's results, MITOMED+ was started in 2017 with the main objective of improving sustainability and responsibility in the field of maritime and coastal tourism by coordination of strategies and sustainable development between regions at a wider Mediterranean, transnational level (MITOMED+, 2020). The focus of MITOMED+ project is: (i) improvement of public policies; (ii) joint planning tools; and (iii) action plans and transfer of practices.

Using a detailed "gap analysis" of economic, environmental, and social challenges in delicate Mediterranean cities and territories, the consortium of the MITOMED+ project agreed to adopt 33 out of the 43 core indicators of the ETIS system (MITOMED+, 2020). Therefore, the consortium defined the set of conceived indicators to be:

- a management tool, supporting destinations that want to take a sustainable approach to destination management;

- a monitoring system, easy to use for collecting data and detailed information and to let destinations monitor their performance from one year to another; and

- an information tool (not a certification scheme), useful for policy makers, tourism enterprises, and other stakeholders (MITOMED+, 2020).

Besides the selection of relevant indicators, an on-line platform as well as application of the best practices has been established to help local and regional policy makers to monitor social and environmental impacts of maritime and coastal tourism (MITOMED+, 2020).

In addition to the projects described so far, there are many others (primarily Interreg) focused on sustainability practices, most of which use the ETIS methodology, with greater emphasis on particular dimensions of sustainability as well as on various geographical scopes (Tab. 2).
Potreba i želja Europske komisija da Europa postane održiva destinacija doprinijele su razvoju velikoga broja EU projekata s fokusom na razvoj pokazatelja. Neki od istaknutijih opisani su u nastavku.

Kako bi se očuvala bogata prirodna i kulturna baština te promovirali mediteranski resursi, od 2014. do 2015. proveden je transnacionalni projekt „MITOMED - Modeli integriranoga turizma na Mediteranu". Uzimajući u obzir MITOMED rezultate, novi projekt „MITOMED+” započeo je 2017. godine s glavnim ciljem: unaprijediti održivost i odgovornost u području pomorskoga i obalnoga turizma koordinacijom strategija i održivoga razvoja među regijama na širem mediteranskom transnacionalnom nivou (MITOMED+, 2020). U središtu pozornosti projekta MITOMED+ bilo je: (i) poboljšanje javnih politika, (ii) alati zajedničkoga planiranja, (iii) akcijski planovi i prijenos praksi.

Detaljnom „analizom jaza” gospodarskih, ekoloških i socijalnih izazova u dragocjenim i osjetljivim mediteranskim gradovima i područjima konzorcij projekta MITOMED+ odlučio je usvojiti 33 pokazatelja, od 43 ključna pokazatelja ETIS-a (MITOMED+, 2020). Stoga je konzorcij definirao skup pokazatelja za koje se smatra da su:

- alat upravljanja, potpora destinacijama koje žele zauzeti održiv pristup upravljanju destinacijom

- sustav praćenja, jednostavan za prikupljanje podataka i detaljnih informacija te za omogućavanje destinacijama da prate njihov rad iz godine u godinu

- informacijski alat (ne sustav certificiranja), koristan tvorcima politika, turističkim poduzećima i drugim dionicima (MITOMED+, 2020).

Osim odabira relevantnih pokazatelja, uspostavljena je online platforma i prijenos najboljih praksi kako bi se lokalnim i regionalnim tvorcima politika pomoglo da prate društvene i ekološke učinke pomorskoga i obalnoga turizma (MITOMED+, 2020).

Osim do sada opisanih projekata, mnogo je projekata (prvenstveno Interrega) usmjerenih na prakse održivosti, od kojih većina koristi ETIS metodologiju, s većim naglaskom na pojedine dimenzije održivosti, kao i na različit geografski fokus (tab. 2). 


\section{Recognised issues and possible solutions}

A number of obstacles and limitations disrupt, slow down or impede the course and successfully implementation of each process, including the process of measuring the sustainability of tourism. In order to comprehend these issues, the main obstacles are defined and the formulation of related problem issues at the destination level are presented below, including possible solutions to overcome these obstacles (Tab.3).

In general, to avoid majority of identified obstacles, a balance between scientific/expert, political, and public approach is crucial, since each approach reflects different priorities. Experience has demonstrated that expert-led development of a measuring framework for sustainable tourism management has a tendency to ignore or underestimated the policy dimension to some extent, and vice versa (Terry, 2008; Holman, 2009, Remetsteiner et al., 2010). To assure adequacy and objectiveness, a measuring framework should be developed via close cooperation between expert-led top-down (TD) and community-led bottom-up (BU) approaches (Bossel, 1999; Blackstock, 2006; Paracchini et al., 2011; Kožić and Mikulić, 2014). This type of collaboration is required to assure social legitimacy and policy, expert, and public consensus. This is especially important in the initial stage of defining baseline issues, key factors, and sustainable tourism indicators, in the order to remove potential subjective bias. Namely, many authors stress that TD indicators neglect stakeholder views and can be too complex and difficult to implement (Bossel, 1999; Tanguay et al., 2013), while BU indicators can be subjective and politicised (McCool et al., 2001; Roberts and Tribe, 2008; Tanguay et al., 2013).

Transparent cooperation among stakeholders, including visitors and the broader community (such as neighbouring destinations), is a good starting point for objectifying the needs of monitoring tourism sustainability. To develop a monitoring framework with reliable indicators, a variety of statistical or non-statistical methods, models, criteria and techniques are available, such as Multi Criteria Analysis (MCA), Delphi method, the DPSIR (Driving force, Pressure, State, Impact, Response) model, the Likert

\section{Prepoznata problemska pitanja i moguća rješenja}

Brojne prepreke i ograničenja ometaju, usporavaju ili ometaju daljnji tijek i uspješnu provedbu svakog procesa, uključujući i proces mjerenja održivosti turizma. Kako bi se ta pitanja obuhvatila, definirane su glavne prepreke i formulirana problematika na razini destinacije, uključujući moguća rješenja za prevladavanje tih prepreka (tab. 3).

Općenito, kako bi se izbjegla većina utvrđenih prepreka, od ključne je važnosti ravnoteža između znanstvenoga/stručnoga, političkoga i javnoga pristupa jer svaki pristup odražava različite prioritete. Iskustvo je pokazalo da stručni razvoj mjernoga okvira za održivo upravljanje turizmom u određenoj mjeri zanemaruje ili podcjenjuje dimenziju politike, ali i obrnuto (Terry, 2008; Holman, 2009; Remetsteiner i dr., 2010). Kako bi se osigurala primjerenost i objektivnost, okvir za mjerenje trebao bi se razviti bliskom suradnjom između pristupa odozgo prema dolje pod vodstvom stručnjaka (top-down) i pristupa odozgo prema gore (bottom-up) vođenih zajednicom (Bossel, 1999; Blackstock, 2006; Paracchini i dr., 2011; Kožić i Mikulić, 2014). Takav oblik suradnje obvezan je da bi se osigurala društvena legitimnost, politički, stručni i javni konsenzus, posebice u početnoj fazi definiranja temeljnih pitanja, ključnih čimbenika i pokazatelja održivoga turizma kako bi se uklonila potencijalna subjektivna pristranost. Naime, mnogi autori ističu da pokazatelji kreirani samo od struke zanemaruju stavove dionika i da ih je prekomplicirano i teško provesti (Bossel, 1999; Tanguay i dr., 2013), dok pokazatelji oblikovani sudjelovanjem lokalne zajednice mogu biti subjektivni i politizirani ( $\mathrm{McCool} \mathrm{i}$ dr., 2001; Roberts i Tribe, 2008; Tanguay i dr., 2013).

Transparentna suradnja među dionicima, uključujući posjetitelje i širu zajednicu (kao što je susjedna destinacija), dobra je polazišna točka za zadovoljavanje potreba praćenja održivosti turizma. Za razvijanje okvira za praćenje s pouzdanim pokazateljima dostupne su različite statističke ili nestatističke metode, modeli, kriteriji i tehnike kao što su višekriterijska analiza (MCA), Delfi metoda, DPSIR okvir (pokretačka snaga, pritisak, država, utjecaj, odgovor), Likertova ljestvica, RACER kriteriji (relevantni, prihvatljivi, vjerodostojni, jednostavani za
I. Marković Vukadin M. Zovko

D. Krešić

Review and evaluation of existing international systems of tourism sustainability indicators

Pregled i evaluacija postojećih

međunarodnih sustava pokazatelja održivosti turizma 
GLASNIK

82/1, 85-110 (2020.) scale, RACER (Relevant, Acceptable, Credible, Easy to monitor, Robust to manipulation) criteria (Miller, 2001; Choi and Sirakaya, 2006; White et al., 2006; Bell and Morse, 2008; Torres-Delgado and Saarinen, 2014), etc. Accordingly, the selected indicators need to strike a balance between their contextual specificity and their global relevance in order to include local, regional, and global impacts. In many cases, sustainable tourism research focuses on local-scale and short-term issues within administratively-de- praćenje, robustni prema manipulacijskim kriterijima) (Miller, 2001; Cho i Sirakaya, 2006; White i dr., 2006; Bell i Morse, 2008; Torres-Delgado i Saarinen, 2014) itd. Prema tome, odabrani pokazatelji trebaju postići ravnotežu između svoje kontekstualne specifičnosti i globalne važnosti kako bi uključili lokalne, regionalne i globalne učinke. U mnogim slučajevima istraživanje održivoga turizma usmjereno je na lokalna i kratkoročna pitanja unutar administrativno definiranih jedinica (Blancas i dr., 2010;

Tab. 3 Obstacles and problem issues in monitoring of sustainable tourism management with suggestions of possible solutions at the destination level Tab. 3. Prepreke i problemi u praćenju održivoga gospodarenja turizmom s prijedlozima mogućih rješenja na razini destinacije

\begin{tabular}{|c|c|c|c|}
\hline $\begin{array}{l}\text { Obstacles / } \\
\text { Ograničenje }\end{array}$ & $\begin{array}{c}\text { Authors identifying the } \\
\text { obstacles / } \\
\text { Autori koji } \\
\text { identificiraju } \\
\text { ograničenja }\end{array}$ & $\begin{array}{l}\text { Problem issues / } \\
\text { Problemsko pitanje }\end{array}$ & $\begin{array}{l}\text { Possible solutions (mechanisms/tools) / } \\
\text { Potencijalno rješenje (mehanizmi/alati) }\end{array}$ \\
\hline $\begin{array}{l}\text { Constrained } \\
\text { cooperation and } \\
\text { understanding } \\
\text { between stake- } \\
\text { holders / } \\
\text { Prepreke uspostavi } \\
\text { suradnje među } \\
\text { dionicima }\end{array}$ & $\begin{array}{l}\text { Bossel (1999); } \\
\text { Terry (2008); } \\
\text { Holman (2009); } \\
\text { Remetsteiner et al. (2010); } \\
\text { Tanguay et al. (2013); } \\
\text { Vojnović (2014); } \\
\text { Krajinović (2015) }\end{array}$ & $\begin{array}{l}\text { How to establish con- } \\
\text { structive and continuous } \\
\text { cooperation? / } \\
\text { Kako uspostaviti kon- } \\
\text { struktivnu i kontinuiranu } \\
\text { suradnju? }\end{array}$ & $\begin{array}{l}\text { - Coordinator is the local decision maker } \\
\text { - Training/visioning workshop/meetings } \\
\text { - } \text { Pocus group discussion } \\
\text { - Koordinator je lokalni donositelj odluka } \\
\text { - Treninzi/radionice planiranja/sastanci } \\
\text { - Rasprave interesnih skupina } \\
\text { - Javni forumi }\end{array}$ \\
\hline $\begin{array}{l}\text { Subjective } \\
\text { stakeholder bias } \\
\text { of selected indi- } \\
\text { cators / } \\
\text { Subjektivna pris- } \\
\text { tranost odabranih } \\
\text { pokazatelja }\end{array}$ & $\begin{array}{l}\text { Bossel (1999); } \\
\text { McCool et al. (2001); } \\
\text { Blackstock et al. (2006); } \\
\text { White et al. (2006); } \\
\text { Roberts and Tribe (2008); } \\
\text { Tanguay et al. (2013); } \\
\text { Kožić and Mikulić (2014) }\end{array}$ & $\begin{array}{l}\text { How to choose indicators } \\
\text { that will objectify measur- } \\
\text { ing of sustainable tourism } \\
\text { management? / } \\
\text { Kako odabrati pokazatelje } \\
\text { koji ce objektivizirati mje- } \\
\text { renje održivoga upravlja- } \\
\text { nja turizmom? }\end{array}$ & $\begin{array}{l}\text { - Formulation of a management strategy and indicator frame- } \\
\text { - Dork } \\
\text { Developing criteria for preference elicitation and mapping of } \\
\text { - Meetings, discussions, and joint analysis on the part of all stake- } \\
\text { holders / } \\
\text { - Formulacija strategije upravljanja i pokazateljskoga okvira } \\
\text { - Izrada kriterija za odabir i kartiranje pokazatelja } \\
\text { - Sastanci, rasprave i analiza dionika }\end{array}$ \\
\hline $\begin{array}{l}\text { Stakeholder } \\
\text { misinformation } \\
\text { about the purpose } \\
\text { of selected indi- } \\
\text { cators / } \\
\text { Dezinformira- } \\
\text { nost dionika o } \\
\text { svrsi odabranih } \\
\text { pokazatelja }\end{array}$ & $\begin{array}{l}\text { Bossel (1999); } \\
\text { Blackstock et al. (2006); } \\
\text { Blancas et al. (2010); } \\
\text { Miller et al. (2010); } \\
\text { Krajinović (2015); } \\
\text { Font (2016) }\end{array}$ & $\begin{array}{l}\text { How to inform stake- } \\
\text { holders about purpose of } \\
\text { measuring sustainable to- } \\
\text { urism management? / } \\
\text { Kako informirati dionike } \\
\text { o svrsi mjerenja održivoga } \\
\text { upravljanja turizmom? }\end{array}$ & $\begin{array}{l}\text { - Introduction of different supportive and ICT solutions } \\
\text { - } \text { Public announcement of the purpose of the policy, measure- } \\
\text { - Infort framework and indicators } \\
\text { (e.g. voluntary contribution)/ } \\
\text { - Uvođenje podražavajućih informacijsko-komunikacijskih teh- } \\
\text { - Javna objava svrhovitosti politike, okvira mjerenja i pokazatelja } \\
\text { - Senzibilizacija javnosti o različitim aspektima održivosti turiz- } \\
\text { ma (npr. dobrovoljno sudjelovanje javnosti) }\end{array}$ \\
\hline $\begin{array}{l}\text { Unavailability of } \\
\text { data needed to } \\
\text { calculate selected } \\
\text { indicators / } \\
\text { Nedostupnost po- } \\
\text { dataka potrebnih } \\
\text { za izračun odab- } \\
\text { ranih pokazatelja }\end{array}$ & $\begin{array}{l}\text { Schianetz et al. (2007); } \\
\text { Blancas et al. (2010); } \\
\text { Tanguy et al. (2013); } \\
\text { Moreno Pires et al. (2014); } \\
\text { Scheyven and Biddulph } \\
\text { (2018); } \\
\text { Torres-Delgado and } \\
\text { Palomeque (2018); } \\
\text { Vojnović (2018) }\end{array}$ & $\begin{array}{l}\text { How to increase the avai- } \\
\text { lability of data? / } \\
\text { Kako osigurati i unaprije- } \\
\text { diti dostupnost podataka? }\end{array}$ & $\begin{array}{l}\text { - } \quad \text { Problem formulation and reflection } \\
\text { - } \text { Formalisation of operative processes (e.g. data collection and } \\
\text { - Communication and public information using formal channels } \\
\text { (e.g. mayor's office, director of tourism's office) } \\
\text { - Gap analysis and identification of other supportive manage- } \\
\text { ment options / } \\
\text { - Formulacija ograničenja i iznalaženje rješenja } \\
\text { - Formalizacija operativnih procesa (npr. prikupljanje podataka i } \\
\text { izrada pokazatelja) } \\
\text { Komunikacija i informiranje javnosti putem službenih kanala } \\
\text { (npr. ured gradonačelnika, direktor turističke zajednice) } \\
\text { Analiza jaza i identifikacija drugih podražavajućih mogućnosti } \\
\text { upravljanja }\end{array}$ \\
\hline
\end{tabular}


Tab. 3 Obstacles and problem issues in monitoring of sustainable tourism management with suggestions of possible solutions at the destination level (continued)

Tab. 3. Prepreke i problemi u praćenju održivoga gospodarenja turizmom s prijedlozima mogućih rješenja na razini destinacije (nastavak)

\begin{tabular}{|c|c|c|c|}
\hline $\begin{array}{l}\text { Obstacles / } \\
\text { Ograničenje }\end{array}$ & \begin{tabular}{|c|} 
Authors identifying the \\
obstacles / \\
Autori koji \\
identificiraju \\
ograničenja \\
\end{tabular} & $\begin{array}{l}\text { Problem issues / } \\
\text { Problemsko pitanje }\end{array}$ & $\begin{array}{l}\text { Possible solutions (mechanisms/tools) / } \\
\text { Potencijalno rješenje (mehanizmi/alati) }\end{array}$ \\
\hline $\begin{array}{l}\text { Costliness of pri- } \\
\text { mary research and } \\
\text { data collection / } \\
\text { Skupoća provedbe } \\
\text { primarnoga } \\
\text { istraživanja i prik- } \\
\text { upljanja podataka }\end{array}$ & $\begin{array}{l}\text { Blackstock et al. (2006); } \\
\text { Ivar (2007); } \\
\text { Latinopoulos and Vagiona } \\
\text { (2013) }\end{array}$ & $\begin{array}{l}\text { How to collect data nee- } \\
\text { ded to calculate the indi- } \\
\text { cators at low (or no) cost?/ } \\
\text { Kako prikupiti podatke i } \\
\text { izraditi pokazatelje? }\end{array}$ & 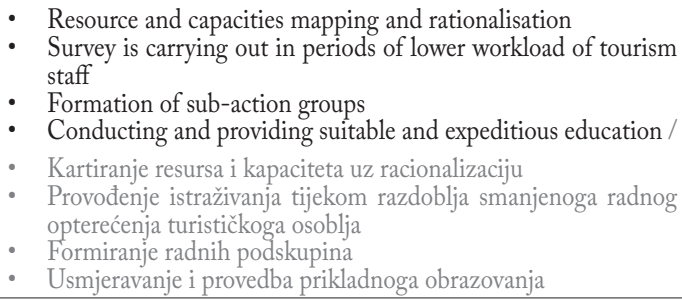 \\
\hline $\begin{array}{l}\text { Unreliability of } \\
\text { data needed to } \\
\text { calculate selected } \\
\text { indicators / } \\
\text { Nepouzdanost po- } \\
\text { dataka za izračun } \\
\text { pokazatelja }\end{array}$ & $\begin{array}{l}\text { Volo and Giambalvo (2008); } \\
\text { Lozano-Oyola et al. (2012) }\end{array}$ & $\begin{array}{l}\text { How to improve quality } \\
\text { and reliability of data? / } \\
\text { Kako unaprijediti kvalite- } \\
\text { tu i pouzdanost podataka? }\end{array}$ & $\begin{array}{l}\text { - Problem formulation and reflections } \\
\text { - Continuous education of database users (e.g. eVisitor) and } \\
\text { tourism staff involved regarding importance of accurate data } \\
\text { entry and measurement } \\
\text { - Working strategy/meetings/ periodic reviews (audit)/ } \\
\text { - Formulacija ograničenja i iznalaženje rješenja } \\
\text { - Kontinuirano obrazovanje korisnika baze podataka (npr. eVisi- } \\
\text { tor) i uključenoga turističkog osoblja } \\
\text { Operativna strategija/sastanci/periodički pregled (audit) }\end{array}$ \\
\hline $\begin{array}{l}\text { Lack of continuity } \\
\text { in stakeholder in- } \\
\text { volvement / } \\
\text { Nepouzdanost po- } \\
\text { dataka za izračun } \\
\text { pokazatelja }\end{array}$ & $\begin{array}{l}\text { Blancas et al. (2011); } \\
\text { Fuchs et al. (2013) }\end{array}$ & $\begin{array}{l}\text { How to ensure continuity } \\
\text { of measurement due to } \\
\text { potential staff changes? / } \\
\text { Kako unaprijediti kvalite- } \\
\text { tu i pouzdanost podataka? }\end{array}$ & $\begin{array}{l}\text { - ICT solutions (database) that contain data/metadata/ indica- } \\
\text { tors /publications, etc. } \\
\text { - Developing the knowledge base } \\
\text { - Transfer of knowledge/ } \\
\text { - Uspostava ICT rješenja (baze podataka) koje sadrži podatke/ } \\
\text { metapodatke /pokazatelje/publikacije } \\
\text { - Razvoj baze znanja } \\
\text { Prijenosa znanja (npr. novom zaposleniku) }\end{array}$ \\
\hline $\begin{array}{l}\text { Incomparability } \\
\text { of calculated } \\
\text { indicators / } \\
\text { Pokazatelji na } \\
\text { godišnjoj razini } \\
\text { nisu usporedivi } \\
\text { s prethodnim } \\
\text { godinama i } \\
\text { konkurentskim } \\
\text { destinacijama }\end{array}$ & $\begin{array}{l}\text { Swarbrooke (2000); } \\
\text { Dann and Chambers } \\
\text { (2013); } \\
\text { Kaurova et al. (2013); } \\
\text { Amin (2017); } \\
\text { Mendola and Volo (2017); } \\
\text { Peeters et al. (2018) }\end{array}$ & $\begin{array}{l}\text { How to distinguish mea- } \\
\text { surement errors from si- } \\
\text { gnificant deviations of the } \\
\text { key factors at the destina- } \\
\text { tion level? / } \\
\text { Kako razlučiti pogrešku } \\
\text { mjerenja od značajnoga } \\
\text { odstupanja uzrokovana } \\
\text { promjenom ključnoga } \\
\text { čimbenika na razini desti- } \\
\text { nacije? }\end{array}$ & $\begin{array}{l}\text { - Determination of deviation and incomparability, and reflection } \\
\text { - Analyses based on comparison with data presented in previous } \\
\text { - Exploring the changes of key factors over the time } \\
\text { - Re-verification of data and indicator accuracy audit in coopera- } \\
\text { tion with data providers / } \\
\text { - Određenje odstupanja, neusporedivost i iznalaženje rješenja } \\
\text { - Provođenje analiza usporedbom podataka iz prethodnih godina } \\
\text { ili podataka konkurentne destinacije } \\
\text { - Istraživanje promjena ključnih čimbenika tijekom vremena } \\
\text { Ponovna verifikacija podataka i pregled točnosti pokazatelja u } \\
\text { suradnji s pružateljima podataka }\end{array}$ \\
\hline
\end{tabular}

Source / Izvor: authors / autori

fined units (Blancas et al., 2010; Torres-Delgado and Palomeque, 2018). In addition, data are often available in relation to administrative units (e.g. municipal or regional) that are not appropriate to interpret the findings, or to make policy decisions (Schianetz et al., 2007). Furthermore, obstacles recorded on data level, including the lack of agreed metrics or measurements of performance, were usually bypassed during the design of monitoring framework and selection of in-
Torres-Delgado i Palomeque, 2018). Osim toga, podatci su često dostupni u odnosu na administrativne jedinice (npr. općinske ili regionalne) koje nisu prikladne za tumačenje nalaza ili donošenje političkih odluka (Schianetz i dr., 2007). Nadalje, prepreke zabilježene na razini podataka, uključujući nedostatak dogovorene metrike ili mjerenje učinkovitosti, obično se zaobilaze pri oblikovanju okvira praćenja i odabiru pokazatelja. Ipak, u okviru za praćenje tre-
D. Krešić

Review and evaluation of existing international systems of tourism sustainability indicators

Pregled i evaluacija postojećih

međunarodnih sustava pokazatelja održivosti turizma 
GEOGRAFSKI

GLASNIK

82/1, 85-110 (2020.) dicators. Nevertheless, in the monitoring framework it should be clearly stated whether the required data are available and how the indicators are calculated and interpreted, which means that data flow and uniform methodology for data processing should be introduced (Bossel, 1999; EEA, 2004). Calculating indicators is still a challenge since we value what we measure, rather than measuring what we value; while data collection is expensive and sustainability data are limited (Torres-Delgado and Saarinen, 2014), and governments can only take policy decisions based on available data (Lozano-Oyola et al., 2012). Finally, understanding of the meaning of indicators requires the definition of the politically-contested process of defining sustainability thresholds (Blancas et al., 2010). The role of local coordinator is crucial due to their involvement throughout the entire process and their primary task of establishing and facilitating co-operation among stakeholders involved in the measurement of tourism sustainability on the destination level. Therefore, it is advisable that local coordinators should have strong policy support-to plan, manage, and oversee setting goals for the process, including presentation of the indicators (Tanguy et al., 2013; Moreno Pires et al., 2014). Formalisation of operative processes and communication using formal channels (e.g. mayor's office) is the basic setting for promotion and cooperation, so data flow can be accelerated to the local coordinator as well as to operators who are responsible for measuring and collecting data and calculating the indicators. In addition, it is advisable to conduct training sessions and planning workshops, and specifically discussion focus groups to search for common ground among those who are involved in measurement tourism sustainability (White et al., 2006; Hall, 2019).

Additionally, obstacles related to the lack of awareness or doubt about the purpose of selected indicators are also possible (Bossel, 1999; Blackstock et al., 2006; Font, 2016). In general, indicators must be simple enough to be understood not only by experts, local coordinators, and operators, but also by the public (Torres-Delgado and Saarinen, 2014). They should be directionally clean (Valentin and Spangenberg, 2000) in order to maintain a clear and understandable channel of communication among variety of stakeholders. Communication strategy and variety of communica- ba jasno navesti jesu li dostupni potrebni podatci i kako se pokazatelji izračunavaju i tumače, što znači da bi trebalo uvesti protok podataka i jedinstvenu metodologiju za obradu podataka (Bossel, 1999; EEA, 2004). Izračun pokazatelja i dalje je izazov jer vrednujemo ono što mjerimo, a ne mjerimo što vrednujemo; dok je prikupljanje podataka skupo, a podatci o održivosti ograničeni (Torres-Delgado i Saarinen, 2014), a vladina tijela mogu donositi političke odluke samo na temelju dostupnih podataka (Lozano-Oyola i dr., 2012). Konačno, razumijevanje značenja pokazatelja zahtijeva politički osporavani proces definiranja pragova održivosti (Blancas i dr., 2010). Za uspjeh procesa važna je i uloga lokalnoga koordinatora koja je ključna zbog njegove uključenosti od samoga početka i njegova je primarna zadaća uspostaviti i olakšati suradnju među dionicima uključenima u mjerenje održivosti turizma na razini destinacije. Stoga je preporučljivo da lokalni koordinator ima snažnu političku podršku zbog svoje uloge - planirati, upravljati i nadgledati postavljene ciljeve procesa, uključujući predstavljanje pokazatelja (Tangurai dr., 2013; Moreno Pires i dr., 2014). Formalizacija operativnih procesa i komunikacija formalnim kanalima (npr. ured gradonačelnika) osnovna je odrednica za promidžbu i suradnju kako bi se protok podataka mogao ubrzati prema lokalnom koordinatoru te operatorima koji su odgovorni za mjerenje i prikupljanje podataka i izračunavanje pokazatelja. Osim toga, preporučljivo je voditi radionice vizije mjerenja i treninge za provedbu, s posebnim fokusom na interesnim skupinama kako bi se pronašli zajednički temelji za one koji su uključeni u mjerenje održivosti turizma (White i dr., 2006; Hall, 2019).

Osim toga, mogle bi se pojaviti i prepreke zbog nedostatka svijesti ili sumnje u svrhu odabranih pokazatelja (Bossel, 1999; Blackstock i dr., 2006; Font, 2016). Općenito, pokazatelji moraju biti dovoljno jednostavni da ih razumiju ne samo stručnjaci, lokalni koordinatori i operateri već i javnost (Torres-Delgado i Saarinen, 2014). Oni bi trebali biti izravno jasni (Valentin i Spangenberg, 2000) kako bi održali jasan i razumljiv kanal komunikacije među različitim dionicima. Komunikacijska strategija i različite komunikacijske tehnike dostupni su kako bi se poduprlo razumijevanje među svim 
tion techniques are available to support understanding among all stakeholders and to adapt methodologies and policies for more integrated and successful destination management (Blackstock et al., 2006; Királová and Pavlíčeka, 2015). Moreover, the communication between stakeholders aimed to raise public awareness regarding aspects of tourism sustainability, as well as to ensure insight into their own role and responsibility in the implementation of sustainable tourism practices (Blackstock et al., 2006; Miller et al., 2010).

Apart from the benefits, the costs of sustainable tourism management and measuring research arise as obstacles (Blackstock et al., 2006; Ivar, 2007; Latinopoulos and Vagiona, 2013), therefore cost efficiency should be well-balanced. Proposal to overcome this issue is to involve a broader range of stakeholders when conducting research, apart from the operators that are nominated on the destination level for this continuous task. This welcome collaboration could be conducted during working hours and accompanied by appropriate guidance and training.

Furthermore, education is a more efficient tool to resolve obstacles, such as unreliability of data used in measuring the sustainability of tourism (Volo and Giambalvo, 2008; Lozano-Oyola et al., 2012). Moreover, information and communication technologies (ICTS) have played an increasingly important role over the last two decades (Höpken et al., 2012), especially in the area of increasing data reliability, enhancing sustainability, and expanding the knowledge base in the field of tourism management. Namely, the majority of the required information and data is stored in databases (e.g. eVisitor) and entered by the tourist staff and by those who are engaged in non-commercial accommodation traffic. Accurate data entry and data reliability is extremely important to avoid existing doubts, but also to explore possibilities to stretch the existing set of indicators, e.g. to measure non-commercial tourist accommodation. The same type of education is necessary for employees of institutions that deal with collecting and disseminating secondary data on the baseline issues such as electricity, water, and waste.

In some cases, the employees involved in the measurement of sustainable tourism management (e.g. operators) are replaced over the course of time (Blancas et al., 2011, Fuchs et al., 2013), while the measurement process itself retains continuity. The dionicima i prilagodile metodologije i politike za integriranije $\mathrm{i}$ uspješnije upravljanje destinacijama (Blackstock i dr., 2006; Kirlova i Pavlíčeka, 2015). Nadalje, komunikacija među dionicima ima za cilj senzibilizirati javnosti o aspektima održivosti turizma te osigurati uvid u vlastitu ulogu i odgovornost u provedbi praksi održivoga turizma (Blackstock i dr., 2006; Miller i dr., 2010).

Osim koristi, kao jedna od prepreka (Blackstock i dr., 2006; Ivar, 2007; Latinopoulos i Vagiona, 2013) javljaju se i troškovi održivoga upravljanja turizmom i mjerenja. Jedan od prijedloga za nadvladavanje ovoga pitanja jest uključivanje širega kruga dionika u provođenje istraživanja, uz operatere koji su imenovani na razini destinacije za ovu trajnu zadaću. Ta bi se dobrodošla suradnja mogla provoditi tijekom radnoga vremena uz odgovarajuće smjernice i obuku.

Nadalje, obrazovanje je učinkovit alat za rješavanje prepreka kao što je nepouzdanost podataka koji se koriste za mjerenje održivosti turizma (Volo i Giambalvo, 2008; Lozano-Oyola i dr., 2012). K tomu, informacijske i komunikacijske tehnologije (ICT) odigrale su u posljednja dva desetljeća sve važniju ulogu (Höpken i dr., 2012), posebice na području povećanja pouzdanosti podataka, povećanja održivosti i proširenja baze znanja na području upravljanja turizmom. Naime, većina traženih informacija i podataka pohranjuje se u baze podataka (npr. eVisitor), a unose ih turistički djelatnici i oni koji obavljaju nekomercijalni smještajni promet. Važnost pravilna unosa podataka i pouzdanost podataka izrazito je važna kako bi se izbjegle postojeće sumnje, ali i istražile mogućnosti rastezanja postojećih pokazatelja, npr. za mjerenje nekomercijalnog turističkog smještaja. Isti tip obrazovanja potreban je zaposlenicima institucija koje se bave prikupljanjem i diseminacijom sekundarnih podataka o osnovnim pitanjima kao što su struja, voda i otpad.

U nekim se slučajevima zaposlenici uključeni u mjerenje održivoga upravljanja turizmom (npr. operateri) mijenjaju tijekom vremena (Blancas i dr., 2011, Fuchs i dr., 2013), dok postupak mjerenja mora imati kontinuitet. Najpouzdanije je rješenje za rješavanje takve prepreke uspostava baze podataka (Höpken i dr., 2012; Pee i Kankanhalli,
I. Marković Vukadin M. Zovko

D. Krešić

Review and evaluation of existing international systems of tourism sustainability indicators

Pregled i evaluacija postojećih međunarodnih sustava pokazatelja održivosti turizma 
GEOGRAFSKI

GLASNIK

82/1, 85-110 (2020.) most reliable solution for dealing with this kind of obstacle is to establish a database (Höpken et al., 2012; Pee and Kankanhalli, 2016) that contains all measurement data, meta-data, and processed indicators, so the transfer of knowledge can be ensured and easily conducted. Establishment of a common database of data and experiences that is easy to share and easy for all stakeholders to access is an important precondition for measuring sustainable tourism development. In addition, the annual data and/or indicators available from almanacs and reports usually provide clear recommendations for following annual data management (Peeters et al., 2018), meaning that new operators can be informed via this channel.

Measurability of data has been commonly identified as an essential component of any indicator (White et al., 2006). Still, there remain a number of issues such as data availability, issues of sampling, and measurement errors (Scheyvens and Biddulph, 2018). Significant deviations in measured values may occur despite a well-defined monitoring framework, established databases, and regardless of accompanying manuals or guidelines. Moreover, 'where data and/or methodology do not exist, knowledge and skills are insufficient to develop new methods or data collection' (White et al., 2006). Additionally, some authors (Swarbrooke, 2000; Dann and Chambers, 2013; Amin, 2017) argue that indicators evaluate sustainability of touristic destination by identifying the key factors of change (e.g. climate change, water availability), which could be accelerated over time. Considering these changes, scientists highlight the cases where data are not in correlation with those measured in the previous years (Kaurova et al., 2013; Mendola and Volo, 2017; Peeters et al.,2018). Therefore, repeated data verification is necessary. If data are still not reliable after re-verification, it should be determined if there has been a significant change in specific key factors at the destination level (EC, 2016; 2019). Consequently, one of the possible solutions for this issue is the introduction of a "new" complementary indicator. It is important to stress that the sets of indicators proposed in the initial measuring framework should be created in a sufficiently flexible manner. This proactive approach is an efficient and useful method for solving variety of obstacles that could be identified in measurement of sustainable tourism management (Tanguay et al., 2013).
2016) koja sadrži sve mjerne podatke, metapodatke i obrađene pokazatelje kako bi prijenos znanja bio osiguran i jednostavan. Realizacija zajedničke baze podataka i iskustava za razmjenu i lakši pristup svim dionicima važan je preduvjet za mjerenje održivoga razvoja turizma. Osim toga, godišnji podatci i/ili pokazatelji dostupni u izdanjima i izvješćima obično pružaju jasne preporuke za sljedeće godišnje upravljanje podatcima (Peeters i dr., 2018), stoga bi se novi subjekti mogli informirati putem toga kanala.

Mjerljivost podataka često je identificirana kao bitna sastavnica svakoga pokazatelja (White i dr., 2006). Ipak, i dalje postoje brojna pitanja kao što su dostupnost podataka te pitanje uzorkovanja i mjerne pogreške (Scheyvens i Biddulph, 2018). Do značajnih odstupanja u izmjerenim vrijednostima može doći unatoč definiranom okviru praćenja, uspostavljenim bazama podataka i neovisno o pratećim priručnicima ili smjernicama. Nadalje, ako podatci i/ili metodologija ne postoje, znanje i vještine nisu dovoljni za razvoj novih metoda ili prikupljanje podataka (White i dr., 2006). Neki autori (Swarbrooke, 2000; Dann i Chambers, 2013; Amin, 2017) tvrde da pokazatelji procjenjuju održivost turističke destinacije identificirajući ključne čimbenike promjena (npr. klimatske promjene, dostupnost vode) koji bi se s vremenom mogli ubrzati. Uzimajući u obzir te promjene, znanstvenici i praksa ističu slučajeve u kojima podatci nisu u korelaciji s podatcima mjerenima prethodnih godina (Kaurova i dr., 2013; Mendola i Volo, 2017; Peeters i dr., 2018.). Stoga je potrebno provesti ponovljenu provjeru podataka. Ako podatci nakon ponovne provjere još uvijek nisu pouzdani, trebalo bi utvrditi je li došlo do značajne promjene specifičnoga ključnog čimbenika na razini destinacije (EC, 2016; 2019). Stoga je jedno od mogućih rješenja toga pitanja uvođenje "novoga” komplementarnog pokazatelja. Važno je naglasiti da bi skup pokazatelja predloženih u početnom okviru mjerenja trebao biti izrađen na dovoljno fleksibilan način. Ovaj proaktivni pristup učinkovit je i koristan način rješavanja različitih prepreka koje se mogu prepoznati u mjerenju održivoga upravljanja turizmom (Tanguay i dr., 2013). 


\section{Conclusion}

Measuring and monitoring the sustainability of tourism over time ceases to be an option, but rather a necessity that emphasises in particular the increasingly widespread issues of over-tourism and problems associated with intensive tourist use. To solve those challenges, the monitoring system with uniformity of measurement and clear models is necessary. For this purpose, numerous international measuring systems for tourism sustainability have been developed, among which ETIS and UNWTO framework are particularly emphasised, and represent the main measurement framework in numerous scientific papers. However, despite the existing systems, confusion because the number of possible systems, and thus the indicators, is constantly increasing, without a clearly defined framework and obligation of measurement. The abundance of systems, initiatives and ultimately the project brings significant perplexity to destination management bodies. Some of the main obstacles to continuous, unified and reliable measurement are: obstacles in establishing cooperation between stakeholders at the destination level, subjective bias of selected indicators, lack of purpose of selected indicators, unavailability of data needed to calculate selected indicators, costliness of primary research and data collection, unreliability of data needed to calculate selected indicators, lack of stakeholders continuous involvement and incomparability of calculated indicators with same indicators produced in previous years and with indicators from competing destinations.

This paper provides wide cross-section analyse of systems, initiatives and projects aimed at monitoring the sustainability of tourism, including the recommendations that the following papers carry out as well as in depth analysis of the indicators and their implementation case studies, with the aim of determining their reliability, measurability and enforceability.

This paper was created as part of an internal scientific project of the Institute for Tourism: Development of integral indicators and carrying capacity model (RIPP) supported by Institute for tourism, Zagreb. We would like to thank to two anonymous reviewers for their useful comments and suggestions.

\section{Zaključak}

Mjerenje i praćenje održivosti turizma s vremenom postaje ne samo mogućnost nego i nužnost koja posebno naglašava sve raširenije probleme prekomjernoga turizma i probleme vezane uz intenzivno korištenje resursa za potrebe turizma. Stoga je nužno koristiti sustav praćenja održivosti kao nužnu osnovu za sustavno praćenje zbog ujednačenosti mjernih i jasnih modela pristupa problemu. $\mathrm{U}$ tu svrhu razvijeni su brojni međunarodni mjerni sustavi za održivost turizma, među kojima su posebno naglašeni ETIS i okvir UNWTO-a, kao glavni okviri u brojnim znanstvenim radovima. Međutim, unatoč postojećim sustavima stvara se zabluda i ne povećava se stvaran doprinos osnovnom znanju o stanju održivosti. Obilje sustava, inicijativa i u konačnici projekata uzrokuje priličnu konfuziju u tijelima zaduženima za upravljanje destinacijama. Neke od glavnih prepreka za kontinuirano, jedinstveno i pouzdano mjerenje jesu: prepreke u uspostavljanju suradnje među dionicima na razini destinacija, subjektivna pristranost odabranih pokazatelja, nedostatak svrhe odabranih pokazatelja, nedostupnost podataka potrebnih za izračun odabranih pokazatelja, skupoća primarnoga istraživanja i prikupljanja podataka, nepouzdanost podataka potrebnih za izračun odabranih pokazatelja, nedostatak kontinuiteta uključenih operatera/koordinatora i neusporedivost izračunatih pokazatelja s istim pokazateljima u prethodnim godinama te s pokazateljima iz konkurentnih destinacija.

Ovaj rad nastojao je dati širok presjek analize sustava, inicijativa i projekata usmjerenih na praćenje održivosti turizma, uključujući preporuke koje bi bilo nužno testirati kroz sljedeće radove, kao i dubinsku analizu pokazatelja i slučajeva njihove primjene s ciljem određivanja njihove pouzdanosti, mjerljivosti i izvršivosti.

Rad je izrađen u sklopu internoga znanstvenog projekta Instituta za turizam: Razvoj integralnoga modela pokazatelja održivosti i prihvatnog (nosivog) kapaciteta u turizmu (RIPP). Željeli bismo zahvaliti dvama anonimnim recenzentima na korisnim komentarima i prijedlozima.

I. Marković Vukadin M. Zovko

D. Krešić

Review and evaluation of existing international systems of tourism sustainability indicators

Pregled i evaluacija postojećih međunarodnih sustava pokazatelja održivosti turizma

Acknowledgement Zahvala 
GEOGRAFSKI

GLASNIK

82/1, 85-110 (2020.)

\section{Literature} Literatura
Agyeiwaah, E., McKercher, B., Suntikul, W., 2017: Identifying core indicators of sustainable tourism: A path forward?, Tourism Management Perspectives 24, 2633, DOI: 10.1016/j.tmp.2017.07.005.

Amin, M., 2017: Domestic tourists' mindset towards responsible tourism management: a case study on Cox's Bazar, Bangladesh, International Journal of Tourism Cities 3 (2), 121-142, DOI:10.1108/ IJTC-09-2016-0028.

Bell, S., Morse, S., 2008: Sustainability indicators: Measuring the immeasurable? (2nd ed.), Earthscan, London.

Blackstock, K. L., Scott, A. J., White, V. McCrum, G., 2006: Indicators and sustainable tourism: Summary of interview findings, The Macaulay Institute, Aberdeen.

Blancas, F. J., Caballero, R., Gonzalez, M. Lozano-Oyola, M., Perez, F., 2010: Goal programming synthetic indicators: an application for sustainable tourism in Andalusian coastal counties, Ecological Economics 69 (11), 2158-2172.

Blancas, F.J., Lozano-Oyola, M., González, M., Caballero, R., 2016: Sustainable tourism composite indicators: a dynamic evaluation to manage changes in sustainability, Journal of Sustainable Tourism 24 (10), 1403-1424, DOI: 10.1080/09669582.2015.1122014

Blažević, V., Hammedi, W., Garnefeld, I. Rust, R.T., Keiningham, T., Andreassen, T.W., Donthu, N., Carl, W., 2013: Beyond traditional word-of-mouth: an expanded model of customer-driven influence, Journal of Service Management 24 (3), 294-313.

Bossel, H., 1999: Indictors for sustainable development: Theory, method, applications, International Institute for Sustainable Development, Winnipeg.

Cabello, J. M., Navarro, E., Prieto, F., Rodríguez, B., Ruiz, F., 2014: Multicriteria development of synthetic indicators of the environmental profile of the Spanish regions, Ecological Indicators 39, 10-23.

Castellani, V., Sala, S., 2010: Sustainable performance index for tourism policy development, Tourism Management 31 (6), 871-880

Ceron, J-P., 2003: Tourism and Sustainable Development Indicators: The Gap between Theoretical Demands and Practical Achievements, Current Issus in Tourism 6 (1), 54-75.

Choi, H. S., Sirakaya, E., 2006: Sustainability indicators for managing community tourism, Tourism Management 27 (6), 1274-1289.

Dann, P., Chambers, L., 2013: Ecological effects of climate change on Little Penguins Eudyptula minor and the potential economic impact on tourism, Climate Research 58, 67-79, DOI: 10.3354/ cr01187.

Dimoska, T., Petrevska, B., 2012: Indicators for Sustainable Tourism Development in Macedonia, in: Conference Proceedings, First International Conference on Business, Economics and Finance "From Liberalization to Globalization: Challenges in the Changing World", 13-15 September, 2012, Stip, Macedonia, 389-400

Državni zavod za statistiku Republike $\mathrm{Hr}$ vatske, 2019: Turizam u 2018, Zagreb, https://www.dzs.hr/Hrv_Eng/publication/2019/SI-1639.pdf (20. 4. 2020.)

Dupeyras, A., MacCallum, N., 2013: Indicators for Measuring Competitiveness in Tourism, OECD Tourism Papers, 2013/02, OECD Publishing, https:// www.oecd.org/cfe/tourism (18.1.2020).

European Environmental Agency (EEA), 2004: European Environment Agency core set of indicators: letter on consultation process on proposal, proposals for a core set of indicators, http://www.eea.eu.int/coreset (12.1.2020.).

European Environment Agency (EEA), 2013a: Indicators and fact sheets about Europe's environment., http://www. eea.europa.eu/data-and-maps/indicators\#c5D\&c7Dall\&c0D10\&b startD0 (12.1.2020.)

European Environment Agency (EEA) 2013b: Multiannual Work Programme 2014-2018: Expanding the knowledge base for policy implementation and longterm transitions, DOI: 10.2800/10814.

European Environment Agency (EEA), 2018: Environmental indicator report 2018, DOI:10.2800/180334

European Commission (EC), 2016: The European Tourism Indicator System ETIS toolkit for sustainable destination management, DOI:10.2873/982144.

European Commission (EC). 2019: European Tourism Indicators System for sustainable destination management, http://ec.europa.eu/growth/sectors/ tourism/offer/sustainable/indicators_en. (18.3.2020.)

Eurostat, 2019: People on the move - statistics on mobility in Europe, Eurostat, Luxembourg, DOI: 10.2785/50487.

Flores, A., Scott, N., 2016: Destination,
Tourism, in: Jafari, J., Xiao, H., (eds.): Encyclopaedia of Tourism, Springer International Publishing, 1-4.

Font, X., 2016: What meaning for sustainability? Creating tourism impacts in a slippery policy context, Journal of Policy Research in Tourism, Leisure and Events 9 (2) DOI: 10.1080/19407963.2016.1258514.

Fuchs, M., Abadzhiev, A., Svensson, B, Höpken, W., Lexhagen, M., 2013: A Knowledge Destination Framework for Tourism Sustainability - a Business Intelligence Application from Sweden, Tourism - An Interdisciplinary Journal 61 (2): 121-148

Gebhard, K., Meyer, M., Roth, S., 2007: Criteria for Sustainable Tourism for the three Biosphere Reserves Aggtelek, Babia Gora and Sumava, Ecological Tourism in Europe (ETE) and UNESCO 3, 15-25.

Global Sustainable Tourism Council (GSTC), 2013a. Global Sustainable Tourism Council Criteria and Suggested Performance Indicators for Hotels and Tour Operators, http://www.gstcouncil.org (8. 12. 2019.)

Global Sustainable Tourism Council (GSTC), 2013b: Global Sustainable Tourism Council Criteria and Suggested Performance Indicators for Destinations, http://www.gstcouncil.org (8.12.2019.).

Giulietti, S., Romagosa, F., Fons, J., Schröder, C., 2016: Developing a "Tourism and Environment Reporting Mechanism" (TOUERM): Environmental impacts and sustainability trends of tourism in Europe, Proceedings of the 14th Global Forum on Tourism Statistics, Venice, Italy, 23-25 November 2016.

Glamuzina, N., 2011: Geografske specifičnosti turističkog razvoja srednjodalmatinskih otoka na prijelazu iz 20. u 21. stoljeće, Hrvatski geografski glasnik 73 (1), 201-214.

Gössling, S., Bredberg, M., Randow, A., Sandström, E., Svensson, P., 2006: Tourist Perceptions of Climate Change: A Study of International Tourists in Zanzibar, Current Issues in Tourism 9, 419-435, DOI: $10.2167 /$ cit265.0.

Grofelnik, H., 2012: Elektroenergetski lokalni ugljikov otisak turizma na otocima Cresu i Lošinju (The local electro-energetic carbon footprint generated by tourism on the islands of Cres and Lošinj), Geoadria 17 (2), 235-244, DPI: 10.15291/geoadria.250.

Hall, C. M., 2019: Constructing sustainable tourism development: The 2030 agenda and the managerial ecology of sustainable tourism, Journal of Sustain- 
able Tourism 27 (7), 1044-1060, DOI: 10.1080/09669582.2018.1560456.

Holman, N., 2009: Incorporating local sustainability indicators into structures of local governance: A review of the literature, Local Environment 14 (4), 365-375.

Höpken, W., Deubele, Ph., Höll, G., Kuppe, J., Schorpp, D., Licones, R., Fuchs, M. 2012: Digitalizing Loyalty Cards in Tourism, in: Fuchs, M., Ricci, F., Cantoni, L. (eds.), Information and Communication Technologies in Tourism, Springer, New York: 272-283.

Interreg Central Europe, 2020: Discover our projects, https://www.interreg-central.eu/Content.Node/projects/projects. html (25. 1. 2020.).

Interreg Mediterranean, 2020: Our projects, https://interreg-med.eu/projects-results/our-projects/ (18. 1. 2020.).

IUCN, 2015: Tourism and Visitor Management in Protected Areas: Guidelines for sustainability, http://www.iucn.org/?18618/ Sustainable-tourism-in-protected-areas-can-be-critical-for-their-survivalsays-new-IUCN-report (12. 10. 2019.).

Ivar, F., 2007: Theorizing indicators: On Indicators, Signs and Trends, Social Indicators Research 83, DOI: 10.1007/s11205006-9061-7.

Kaurova, O., Maloletko, A., Yumanova, O., 2013: Cross-country Comparison of Statistical Indicators, Life Science Journal 10 (4), 1915-1917.

Királová, A., Pavlíčeka, A., 2015: Development of Social Media Strategies in Tourism Destination, Procedia - Social and Behavioral Sciences 175, 358-366, DOI: 10.1016/j.sbspro.2015.01.1211.

Klanjšček, J., Geček, S., Marn, N., Legović, T., Klanjšček, T., 2018: Predicting perceived level of disturbance of visitors due to crowding in protected areas, PloS one 13 (6), DOI: e0197932.

Kožić, I., Mikulić, J., 2014: Measuring tourism sustainability - an empirical comparison of different weighting procedures used in modelling composite indicators, Tourism economics 20 (2), 429-439.

Krajinović, V., 2015: Propitivanje ključnih izazova u mjerenju održivog razvoja turizma (Challenging the key issues in measuring sustainable tourism development), Acta turistica 27 (1), 63-91.

Kunasekaran, P, Gill, S. S., Ramachandran, S., Shuib, A., Baum, T.,Mohammad Afandi, S.H., 2017: Measuring Sustainable Indigenous Tourism Indicators: A Case of Mah Meri Ethnic Group in
Carey Island, Malaysia, Sustainability 9, 1256; doi:10.3390/su9071256.

Lacitignola, D., Petrosillo, I., Cataldi, M., Zurlini, G., 2007: Modelling socioecological tourism-based systems for sustainability, Ecological Modeling 206 (1), 191-204.

Latinopoulos, D., Vagiona, D., 2013: Measuring the sustainability of tourism development in protected areas: an indicator-based approach, International Journal of Innovation and Sustainable Development 7 (3), 233-251.

Lew, A. A., Ng, P.T., Ni, C. C, Wu, T., 2016: Community sustainability and resilience: similarities, differences and indicators, Tourism Geographies 18 (1), 18-27, DOI: 10.1080/14616688.2015.1122664.

Lozano Oyola, M., Blancas Peral, F., Lozano, M., Caballero, R., 2012: Sustainable tourism indicators as planning tools in cultural destinations, Ecological Indicators, 18:659-675, DOI: 18. 659-675. 10.1016/j.ecolind.2012.01.014.

Marić, K., Samardžić, B., Protrka, N., 2017: Analiza turističkih pokazatelja i sigurnost u turizmu Republike Hrvatske te mogućnosti jačanja konkurentnosti hrvatskog turizma nakon ulaska u Europsku Uniju, Obrazovanje za poduzetništvo 7 (1), 301-318.

Marzo-Navarro, M., Pedraja-Iglesias, M., Vinzón, L., 2015: Sustainability indicators of rural tourism from the perspective of the residents, Tourism Geographies 17, 586-602, DOI: 10.1080/14616688.2015.1062909.

McCool, S. F., Moisey, R. N., Nickerson, N. P., 2001: What Should Tourism Sustain? The Disconnet with Industry Perceptions of Useful Indicators, Journal of Travel Research 40, 124-131.

Mendola, D., Volo, S., 2017: Building composite indicators in tourism studies: Measurements and applications in tourism destination competitiveness, Tourism Management 59, 541-553, DOI: 10.1016/j.tourman.2016.08.011.

Miller, G., 2001: The development of indicators for sustainable tourism: results of a Delphi survey of tourism researchers, Tourism Management 22, 351-362.

Mikulić, J., Kožić, I., Krešić, D., 2015: Weighting indicators of tourism sustainability: A critical note, Ecological Indicators 48, 312-314, DOI: 10.1016/j. ecolind.2014.08.026

MITOMED+, 2020: Models of Integrated TOurism in the MEDiterranean, https://mitomed-plus.interreg-med.eu/

\section{$(12.1 .2020)$}

Moreno Pires, S., Fidélis, T., Ramos, T., 2014: Measuring and comparing local sustainable development through common indicators: Constraints achiev, Cities 39, 1-9, DOI: 10.1016/j.cities.2014.02.003.

Mrak-Taritaš, A., 2010: Uvjeti planiranja i prostorni pokazatelji uređenja turističkih predjela Babin Kuk i Solaris, Prostor 18 (1), 136-151.

Opačić, V.T., 2008: Ekonomsko-geografski utjecaji i posljedice vikendaštva u receptivnim vikendaškim područjima - primjer otoka Krka, Ekonomska misao i praksa 17 (2), 127-154.

Paracchini, M. L., Pacini, C., Jones, M. L. M., Perez-Soba, M., 2011: An aggregation framework to link indicators associated with multifunctional land use to the stakeholder evaluation of policy options, Ecological Indicators 11 (1), 71-80.

Pee, L. G., Kankanhalli, A., 2016: Interactions among factors influencing knowledge management in public-sector organizations: A resource-based view, Government Information Quarterly 33 (1), 188-199.

Peeters, P., Gössling, S., Klijs, J., Milano, C., Novelli, M., Dijkmans, C.,Postma, A., 2018: Research for TRAN Committee - overtourism: Impact and possible policy responses: European Parliament, Policy Department for Structural and Cohesion Policies, Brussels.

Pepeonik, Z., 1988: Osnovni prostorni pokazatelji turizma u Jugoslaviji, Acta Geographica Croatica 23 (1), 23-34.

Pletikosa, D., 2015: Prijedlog modela mjerenja konkurentnosti turizma i hotelijerstva Hrvatske, Ekonomski pregled 66 (6), 579-608.

Pulido, J. I., Sánchez, M., 2009: Measuring tourism sustainability: proposal of a composite index, Tourism Economics 15 (2), 277-296.

Rametsteiner, E., Pülzl, H., Alkan-Olsson, J., Frederiksen, P., 2010: Sustainability indicator development: Science or political negotiation?, Ecological Indicators 11 (1), 61-70.

Roberts, S., Tribe, J., 2008: Sustainability indicators for small tourism enterprises - An exploratory perspective, Journal of Sustainable Tourism 16 (5), 575-594.

Scheyvens, R., Biddulph, R., 2018: Inclusive tourism development, Tourism Geographies 20 (4), 589-609, DOI: 10.1080/14616688.2017.1381985
I. Marković Vukadin M. Zovko

D. Krešić

Review and evaluation of existing international systems of tourism sustainability indicators

Pregled i evaluacija postojećih međunarodnih sustava pokazatelja održivosti turizma 
GEOGRAFSKI

GLASNIK

82/1, 85-110 (2020.)

Authors

Autori
Schianetz, K., Kavanagh, L., Lockington, D., 2007: The Learning Tourism Destination: The potential of a learning organisation approach for improving the sustainability of tourism destinations, Tourism Management 28, 1485-1496, DOI: 10.1016/j.tourman.2007.01.012.

Slavuj, L., Čanjevac, I., Opačić, V. T., 2009: Vodoopskrba kao faktor održivog razvoja turizma otoka Krka, Hrvatski geografski glasnik 71 (2), 23-41.

Swarbrooke, J., 2000: Tourism, economic development and urban regeneration: a critical evaluation, in: Robinson, M., Sharpley, R., Evans, N., Long, P. Swarbrooke, J. (Eds.), Developments in Urban and Rural Tourism, Business Education Publishers Ltd, London, 269-286.

Šulc, I., Valjak, V., 2012: Zaštićena područja u funkciji održivog razvoja hrvatskog otočja - primjer otoka Mljeta, Hrvatski geografski glasnik 74 (1), 161-185, DOI: 10.21861/HGG.2012.74.01.09.

Tanguay, G. A., Rajaonson, J., Therrien, M. 2013: Sustainable tourism indicators: selection criteria for policy implementation and scientific recognition, Journal of Sustainable Tourism 21 (6), 862-879, DOI: 10.1080/09669582.2012.742531.

Terry, A., 2008: Community sustainable-development indicators: A useful participatory technique or another dead end? Development in Practice 18 (2), 223-234.

Torres-Delgado, A.; Saarinen, J., 2014 Using indicators to assess sustainable tourism development: A review, Tourism Geographies 16 (1), 31-47, DOI: 10.1080/14616688.2013.867530

Torres-Delgado, A., Palomeque, F., 2012: The growth and spread of the concept of sustainable tourism: The contribution of institutional initiatives to tourism policy, Tourism Management Perspective 4, 1-10,
DOI: 10.1016/j.tmp.2012.05.001.

Tsaur, S. H., Lin, Y. C., Lin, J. H., 2006: Evaluating ecotourism sustainability from the integrated perspective of resource, community and tourism, Tourism Management 27 (4), 640-653.

United Nations (UN), 1997: Glossary of environment statistics, UN Department for Economic and Social Information and Polity Analysis, New York

United Nations Environment Programme (UNEP) and World Tourism Organization (UNWTO), 2012: Tourism in the Green Economy - Background Report, UNWTO, Madrid.

UNDP, 2014: Tourism Concessions in Protected Natural Areas: Guidelines for Managers. http://www.undp.org/content/ undp/en/home/librarypage/environment-energy/ecosystems_and_biodiversity/tourism-concessions-in-protected-Natural-areas.html (15.12. 2019.)

UNWTO/UNEP/IUCN, 2002: Sustainable Tourism in Protected Areas: Guideline for Planning and Management, IUCN, Gland, Switzerland and Cambridge, UK

Valentin, A., Spangenberg, J. H., 2000: A guide to community sustainability indicators, Environmental Impact Assessment Review 20 (3), 381-392.

Vizek, M., 2008: An Analysis of Tourism Sector Determinants in Croatia (Analiza odrednica hrvatskog turističkog sektora), Privredna kretanja i ekonomska politika 18 (114), 50-81.

Vojnović, N., 2013: Sociokulturna obilježja održivog turizma unutrašnje Istre, Socijalna ekologija, 22 (2), 85-106.

Vojnović, N., 2014: Problematika implementacije temeljnih indikatora održivog turizma u hrvatskim općinama i gradovima. Ekonomska misao i praksa 1,171-190.
Volo, S., Giambalvo, O., 2008: Tourism Statistics: Methodological Imperatives and Difficulties: The Case of Residential Tourism in Island Communities1, 3. Current Issues in Tourism 11, 369-380, DOI: $10.1080 / 13683500802140398$.

White, V., McCrum, G., Blackstock, K. L., Scott, A., 2006: Indicators and Sustainable Tourism: Literature Review, Macaulay Institute, Aberdeen. World Tourism Organization (UNWTO), 1998: Guide for Local Authorities on Developing Sustainable Tourism, World Tourism Organization, Madrid.

World Tourism Organization (UNWTO), 2004: Indicators of Sustainable Development for Tourism Destinations A Guidebook, World Tourism Organization, Madrid.

World Tourism Organization (UNWTO), 2008: International Recommendations for Tourism Statistics, World Tourism Organization, New York.

World Tourism Organization (UNWTO), 2015: The 10 Year Framework of Programmes on Sustainable Consumption and Production Patterns (10YFP), World Tourism Organization, New York.

World Tourism Organization (UNWTO) 2017: Measuring Sustainable Tourism: $A$ call for Action - Report of the 6th International Conference on Tourism Statistics, Manila, Philippines, 21-23 June 2017, Madrid, DOI: https://doi. org/10.18111/9789284418954

World Tourism Organization, Organization of American States (UNWTO and OAS), 2018: Tourism and the Sustainable Development Goals - Good Practices in the Americas, Madrid, DOI:10.18111/9789284419685.
Izidora Marković Vukadinｉzidora.markovic@iztzg.hr

PhD, Research Associate, Institute for Tourism, Vrhovec 5, 10000 Zagreb, Croatia
Mira Zovko
mira.zovko@mzoe.hr
Ministry of Environment and Energy of the Republic of Croatia, Radnička cesta 80, 10000 Zagreb, Croatia

\section{Damir Krešić damir.kresic@iztzg.hr \\ PhD, Senior Research Associate, Institute for Tourism, Vrhovec 5,} 10000 Zagreb, Croatia 